\title{
El feto agresivo. \\ Parto, formación de la persona y mito-historia en los Andes*
}

\author{
Tristan Platt \\ Department of Social Anthropology, \\ University of St Andrews. \\ Escocia, Reino Unido
}

\begin{abstract}
Partiendo de un estudio etnográfico y lingüístico sobre la mortalidad materna en Bolivia, este trabajo etno-obstétrico trata de la concepción, la gestación y el parto en una comunidad quechua-hablante de Potosí. Analiza el paralelismo planteado entre la formación temprana de la persona y los orígenes mito-históricos de la sociedad. La sustancia pagana pre-hispánica fluye constantemente hacia una sociedad de conversos, dando realidad al concepto jurídico de "indio originario". Se propone superar la oposición entre las interpretaciones "esencialistas" e "hibridistas" de la sociedad indígena, al mostrar que el "originario" necesariamente se construye por los comuneros como "esencial", pero sin por eso negar su constante transformación histórica. Los ritos de separación del "feto agresivo" de la madre también plantean preguntas a los psicoanalistas sobre la influencia que pueden tener las experiencias perinatales sobre la formación individual en diferentes contextos históricos y culturales.
\end{abstract}

Una amplia gama de lecturas etno-obstétricas de los cuerpos de las mujeres embarazadas sigue orientando las prácticas del parto en todo el mundo. ${ }^{1}$ Estas lecturas, que se dan en los márgenes del modelo biomédico dominante, representan diferentes perspectivas culturales sobre los procesos fisiológicos, y permiten formas igualmente variadas de atención práctica a las parturientas. Las ideas sobre la gestación, por ejemplo, pueden llevar a las madres a diagnosticar el estado y el sexo de su bebé a partir de sus movimientos, y a las parteras a administrar pociones o intervenir directamente con sus manos para palpar o reposicionar una imagen cultural del feto dentro del cuerpo de la madre. Otras ideas, expresadas mediante el rito y la invocación, pueden indicar un conjunto de correspondencias embutidas

* E-mail: tp@st-and.ac.uk. Agradezco a Barbara Bradby, Concepción Gavira, Jo MurphyLawless y Patricia Oliart conversaciones con respecto al tema de este trabajo, y a Berta Ares la revisión del texto castellano.

1 MacCormack, Carolyn (comp.): Ethnography of Fertility and Birth. New York, 1982. Jordan, Brigitte: Birth in Four Cultures. New York, 1978. Davis-Lloyd, R.E. \& Sargent, Carolyn (comps.): Childbirth and Authoritative Knowledge. Cross-Cultural Perspectives. University of California Press, 1997. 
que sitúan a la madre como microcosmos en relación a más amplios procesos espacio-temporales de gestación y transformación. Claude LéviStrauss ${ }^{2}$ ha sostenido que, entre los Kuna de Panamá, el mito y el canto pueden proporcionar una terapia eficaz a una madre cuyo proceso de parto se encuentra bloqueado, al estimular su imaginación mítica hacia una relación psicosomática con su cuerpo. De esta manera, se rechaza la división mentecuerpo que está en la base de la obstetricia biomédica. Sheila Kitzinger, quien mantiene que una sociología comparativa del parto requiere un estudio de las relaciones entre los sistemas de significación, el comportamiento social y el estado fisiológico, también aboga por mayores investigaciones sobre las asociaciones que pueden existir "entre los tipos de sostén psicológico, que se dan en distintas sociedades, y la función uterina".

La frase "sostén psicológico" debe tomarse en un sentido amplio, en tanto en cuanto las ideas que mueven los cuerpos culturalmente construidos, también pueden expresar el miedo y la ansiedad de las parturientas sobre el dolor y la mortalidad. Las soluciones etno-obstétricas raras veces intentan justificarse en términos de la "minimización del riesgo", tal cómo se plantea por la obstetricia biomédica. Más bien se enfatiza la inevitable proximidad entre la vida y la muerte. ${ }^{4}$ En los Andes, esto puede conducir a un énfasis sobre las características agresivas y peligrosas del feto, con el que la mujer debe luchar, a riesgo de su vida, para poder expulsarlo durante el parto. $\mathrm{Al}$ mismo tiempo, el nacimiento del individuo se relaciona con un cataclismo mito-histórico que habría estado en los orígenes de la misma sociedad. Las almas ancestrales pre-cristianas son pensadas como pequeños "diablos" gentiles, que moran dentro de la tierra (ukhu pacha) y deben entrar en los vientres de las mujeres para dar vida y energía a los embriones humanos en gestación. De tal modo que los antepasados paganos se reencarnan como bebés cristianos, proceso que se percibe como análogo a la conversión religiosa de la sociedad andina en el siglo XVI. La gestación del feto adquiere, de esta manera, asociaciones cósmicas. ¿Por qué este paralelismo entre los procesos mito-históricos e individuales de gestación, transformación y renacimiento? ¿entre la dinámica de las épocas históricas y la producción cotidiana de nuevas personas?

2 Lévi-Strauss, Claude: "The Effectiveness of Symbols", en Structural Anthropology. New York, 1963 [1958].

3 Kitzinger, Sheila: "The Social Context of Birth: some comparisons between Childbirth in Jamaica and Britain". En MacCormack (comp.): Ethnography of Fertility ...

4 Murphy-Lawless, Jo: Reading Birth and Death. A History of Obstetric Thinking. Cork University Press, 1998. 
Las aproximaciones antropológicas a menudo consideran el parto como un elemento dentro de la reproducción biológica y social de una sociedad situada en algún presente etnográfico. Sin embargo, allí donde las grandes transiciones históricas se sacralizan mediante la conversión religiosa, la memoria de esta transición puede servir para conceptualizar el nacimiento de las personas. Así, Altan Gokalp ha mostrado como, en Anatolia, la dualidad de la pareja primordial, compuesta de un dios celeste y una diosa placentaria, ésta última vista como el origen de las almas de los niños nonacidos, con la llegada del Islam fue reemplazada por un único dios celeste identificado con Alá. Al mismo tiempo, la diosa placentaria se transformó en una demonio agresiva, que atacaba a las mujeres parturientas y a sus bebés. El equilibrio genérico se convirtió en antagonismo, y la fuente femenina de la vida en fuente de agresión demoníaca, siguiendo la instalación de la teología patriarcal islámica. Gokalp interpreta este cambio histórico al referirse a una visión pre-islámica del feto como vinculado a la placenta más que a la madre, formando una pareja ambivalente incrustada dentro del vientre. $^{5}$

La misma analogía entre el parto humano y una transición mito-histórica se da en los Andes. Según un mito ampliamente difundido, el tránsito desde la edad de los antepasados lunares o Chullpa a la edad del Sol inka y cristiano ${ }^{6}$ fue un acontecimiento traumático en cuanto que el Sol naciente disecó a los antepasados, convirtiéndoles en momias, y sus casas en las tumbas funerarias que aún se agrupan en diferentes partes del paisaje altoandino. ${ }^{7}$ Los únicos Chullpa que escaparon de los rayos ardientes del Sol fueron aquéllos que vivían al lado de los ríos y lagos, en los cuales se hundieron para convertirse en los actuales Uru-Chipaya, o "gente del agua". ${ }^{8}$ Pero los antepasados chullpa conservan su posición como antepasados de los indios actuales, a través de la creencia de que sus almas paganas se reencarnan dentro del vientre de cada madre india, para transformarse en cristianos mediante ritos post-natales de separación y bautismo. Esta transformación,

5 Gokalp, Altan: “Le Placenta, ou l'Épouse Déchue du Dieu-Ciel”, en Singularités: les Voies d'Émergence Individuelle. Textes pour Eric de Dampierre présentés par le Laboratoire d'Ethnologie et de Sociologie Comparative. París, 1989.

6 En Macha, el contraste entre la época lunar y la época solar tiene más importancia que la distinción entre las épocas pre- y post-Conquista. De ahí que he encontrado conveniente contrastar un período "inka-hapsburgo" solar, en su conjunto, con la anterior época lunar de los Chullpa.

7 Estas tumbas se asocian con el período arqueológico conocido como el Intermedio Tardío (ca.1000-1450 DC), aunque en la región del lago Titicaca una nueva tradición de construcción de tumbas de piedra fue introducida por el Inka en las décadas previas a la invasión española.

8 Wachtel, Nathan: Le rétour des ancêtres. París, 1990. 
que repite a nivel de cada individuo la conversión solar-cristiana de las sociedades andinas, tiene importantes consecuencias para la construcción de la persona entre los indios originarios. Como veremos, significa que cada persona india sigue construyéndose, individualmente, como un cristiano пиеvo.

La oposición entre nuevos y viejos cristianos es fundamental para comprender las ideas de pureza de sangre y contaminación en las que se basó la sociedad estamental hispánica. Los cristianos viejos fundamentaron sus pretensiones a la nobleza y a los privilegios en la descendencia de sangre y en la residencia en el norte cristiano viejo de la Península. Esto les permitió proyectarse como herederos legítimos de la cristiandad premusulmana de romanos y visigodos, y como quienes habían expulsado heroicamente a los musulmanes tras quinientos años de reconquista. Por otra lado, los cristianos nuevos, como los marranos y los moriscos, vivían bajo la continua sospecha de herejía por parte de la Inquisición. ${ }^{9}$ Sin embargo, en la América colonial - como tantas otras veces- las cosas podían invertirse. Los nuevos cristianos andinos, por ejemplo, podían pretender ser más cristianos que los cristianos viejos españoles, cuya opresión tiránica algunos (como es el caso de Waman Puma) denunciaron incluso como no cristiana. ${ }^{10} \mathrm{Al}$ mismo tiempo, la conexión con el pasado gentil fue necesaria tanto como punto de referencia frente al cual medir la violencia colonial española, ${ }^{11}$ como para constituir la categoría fiscal colonial de indio originario. Para los indígenas, la conversión de un estado anterior de gentilidad fue un requisito para mantener sus derechos a la tierra bajo el gobierno español. Por lo tanto, el problema para los nativos andinos fue cómo compatibilizar la autoctonía, que necesariamente implicaba la descendencia substantiva desde los paganos, con su "re-nacimiento" como conversos andino-cristianos. Parte de la solución parece haber consistido en repetir el proceso de conversión con cada nuevo nacimiento. De este modo, podían afirmar una continuidad esencial con los paganos muertos, al mismo tiempo que reafirmaban su transformación histórica en nuevos cristianos. Tal solución trasciende la simple oposición entre "esencialismo" e "hibridis-

9 Cardaillac, Louis: Morisques et Chrétiens. Un affrontement polémique (1492-1640). París, 1977. Wachtel, Nathan: "Francisco Maldonado de Silva. 'Le ciel face à face"”, Annales H, SS. París, 1999.

10 Silverblatt, Irene: "New Christians and New World Fears in Seventeenth-Century Peru", Comparative Studies in Society and History. Vol 42 No 3. 2000.

11 Ver Asssadourian, Carlos Sempat: “ 'La Gran Vejación y Destruición de las Indias’: Las Guerras de Sucesión y de Conquista en el Derrumbe de la Población Indígena del Perú", en Transiciones hacia el Sistema Colonial Andino. Lima, 1994. 
mo" que, últimamente, ha provocado mucho debate, al representar a la persona india como, a la vez, esencial $e$ históricamente transformada. ${ }^{12}$

En este artículo, examinaré la periodización de la gestación y el parto en Macha, un gran ayllu de quechua-hablantes en el Norte de Potosí (provincia de Chayanta, Departamento de Potosí, Bolivia). Voy a considerar las ideas y las prácticas en torno a la concepción y embarazo, para después analizar los ritos de separación que marcan la entrada de cada bebé al reino de la cristiandad solar. La emergencia dolorosa de cada persona en la sociedad macha, mediante las acciones de la madre, del feto y de los asistentes al parto, aparecerá como la repetición en microcosmos de la transformación solar-cristiana de la sociedad pagana, ambas situadas dentro del fresco escatológico de la cristiandad misionera. Al mismo tiempo, el feto aparecerá como una entidad voraz, que absorbe sangre hasta poner en peligro la vida de su madre, quien debe librar una esforzada lucha para salvarse de esta amenaza mortal. Terminaré con algunos comentarios sobre la relación entre la persona y la conversión en las sociedades sujetas al proselitismo violento, y la relevancia de una "historia de los acontecimientos" para los debates actuales sobre las políticas de salud reproductiva.

\section{Embarazo, enfermedad y muerte}

El siguiente análisis se basa en veinticinco entrevistas extensas, realizadas en quechua en 1994-95, con madres y padres de diferentes edades, y con parteros y parteras, todos ellos residentes en la región de la baja puna (c.3800 msnm) del territorio de los Macha. ${ }^{13}$ En el siglo XVI, los Macha eran el gran ayllu dominante dentro de la federación aymara y provincia

12 Ver Harris, Olivia: To Make the Earth Bear Fruit. Ethnographic Essays on Fertility, Work and Gender in Highland Bolivia. Londres, 2000. Harris rechaza la crítica del "andinismo" desarrollada por Orin Starn por "orientalista", al aclarar el contexto político donde se desarrollaron el indigenismo y el "andinismo" en los mismos paises andinos. Por mi parte, en este artículo intento aclarar, sobre un período temporal más amplio, las influencias políticas sobre las estrategias indias de auto-construcción, a través de un análisis de las prácticas de parto y de las representaciones comunitarias de la formación de la persona originaria o "autóctona".

13 La mayoría de los entrevistados son del cabildo Pichhichua, del ayllu menor AlaQuyana, mitad Alasaya, de Macha; algunos han conocido al autor desde 1971. Para la organización social de Macha, ver Platt, Tristan, "Mirrors and Maize: the concept of yanantin among the Macha of Bolivia", en Murra, John, Wachtel, Nathan y Revel, Jacques (comps.): Anthropological History of Andean Polities. Cambridge, 1986 [1978]. Hoy, los Macha hablan un dialecto potosino del quechua sureño, con fuertes influencias del aymara y del castellano. Las entrevistas se llevaron a cabo en quechua por el autor, Balbina Arancibia y Primitivo Nina, éstos últimos hablantes nativos del quechua potosino. Cada entre- 
inka de Qaraqara. Hoy, después de cuatrocientos cincuenta años de persistencia empedernida, ${ }^{14}$ las más recientes fuerzas de la modernización han debilitado, dividido y, en parte, disuelto la organización de esta sociedad dual, que abarca desde la puna alta y fría hasta los valles calientes, y que encontré ya fracturada y marginada durante mi primer trabajo de campo (1970-71). Sin embargo, los campesinos de Macha se han adaptado y apropiado de la modernidad mercantil cristiana desde sus inicios, en el siglo XVI, en función del desarrollo de las minas de plata de Porco y Potosí. Así pues, los procedimientos y las creencias que voy a describir deben entenderse como el fruto de un proceso secular de ajuste reflexivo, auto-modernización activa e intervención política. De hecho, algunas entrevistas muestran nuevos esfuerzos por negociar y acomodarse en relación a las actuales políticas de salud reproductiva, que emanan de los puestos médicos locales y de los hospitales. Estas políticas están transformando prácticas específicas sin disolver, hasta ahora, ciertas premisas básicas de las aproximaciones macha al parto, premisas que el siguiente análisis intentará poner de manifiesto.

El proyecto más amplio, en el que se enmarcó esta investigación, enfatizaba los peligros que afectan a las madres, y sólo secundariamente la perspectiva del bebé. ${ }^{15}$ Pensamos que las políticas de salud reproductiva han desplazado la atención prioritaria desde la madre hacia el bebé, de una manera a menudo perjudicial para las mujeres. Esta opinión fue compartida por nuestros informantes: la muerte de un bebé es motivo de lágrimas y lamentaciones, pero no tiene ni remotamente el significado traumático de la muerte de

vista fue transcrita, traducida al castellano andino regional, y anotada en discusión con los entrevistados. Se elaboró un vocabulario general del quechua usado en las entrevistas sobre el parto. También se presentó un cuestionario cerrado a 23 madres, algunas entre las previamente entrevistadas, cuyos resultados también se han utilizado, junto con el anterior trabajo etnográfico y etnohistórico del autor.

14 Platt, Tristan: La persistencia de los ayllus en el Norte de Potosí. De la Invasión Europea a la República de Bolivia. La Paz, 1999.

15 Maternal Mortality and Appropriate Methods of Childbirth. El proyecto más amplio fue elaborado por el Centre of Women's Studies, Trinity College Dublin, y financiado por la Comisión Europea DG XII. El autor y Balbina Arancibia participaron en el subproyecto de Macha por la Universidad de St Andrews, y Primitivo Nina por el Taller de Investigación y Formación Académica y Popular (TIFAP, Sucre, Bolivia). Agradezco a Verena Stolcke por haberme invitado a presentar una primera versión del presente trabajo en el Departamento de Antropología y Prehistoria de la Universidad Autónoma de Barcelona (1998); a Carmen Gómez por la invitación a presentarlo en el Departamento de Historia de la Universidad de Sevilla (1998), y a Nathan Wachtel, Jacques Poloniy y Gilles Rivière, quienes me invitaron a pasar una estancia como Directeur d'Études Invité en la École des Hautes Études en Sciences Sociales (París), donde pude presentar el trabajo en el Centre des Récherches sur les Mondes Amerindiens (CERMA) (1999). El trabajo también fue presentado en un seminario en memoria del antropólogo Gabriel Martínez, recién fallecido, en el Museo de Azapa, Universidad de Tarapacá (Chile), como parte del Proyecto 1990200 de FONDECYT (Chile), dirigido por Vivián Gavilán, del Taller de Estudios Andinos, Arica (2000). 
la madre, quien normalmente es un miembro en plenas funciones dentro de la sociedad local. De ahí que nuestra investigación tuviera una dimensión aplicada: la reducción de la mortalidad materna, y esto condujo a un énfasis sobre las ideas y prácticas referentes a la enfermedad perinatal y la muerte.

Un problema relacionado con esta preocupación fue hasta dónde era lícito decir que cada mujer ejercía una agencia en el manejo de su propio parto. Los enfoques estadísticos y de reducción de riesgos han conducido a una situación donde ha llegado a ser muy difícil, en la bio-medicina metropolitana, reconocer un parto "normal", salvo retrospectivamente. Esto se vincula con el desarrollo de la obstetricia médica y la hospitalización del acto de parir en las sociedades noratlánticas ${ }^{16} \mathrm{y}$ nos condujo a preguntarnos cuál podría considerarse un parto "normal" en Macha. Encontramos que éste sería un parto doméstico, donde la madre era atendida, principalmente, por su marido e hijos: los mas jóvenes apartados para que no se asustasen por los gritos de la madre, y los mayores haciendo hervir agua, preparando infusiones y buscando utensilios. Un parto "normal" es, pues, un asunto doméstico, íntimo, que concierne sobre todo a la unidad familiar en la cual está naciendo el bebé. Una pareja poco experimentada puede pedir ayuda, sobre todo para su primer hijo, a la madre del marido, ${ }^{17} \mathrm{o}$ a otra mujer local con experiencia, que resida cerca de la estancia de la parturienta. En el caso de complicaciones, se buscará la ayuda de una partera especializada, que puede venir desde más lejos. ${ }^{18}$ Además, la compañía de hombres, que mascan coca mientras vigilan, también tranquiliza a la madre y la protege de los duendes predatorios (q'ara wawas: "bebés desnudos"), considerados una grave amenaza para la vida de las parturientas. En un caso nos informaron de un parto especialmente difícil, que fue acompaña-

16 Foucault, Michel: The Birth of the Clinic. Londres, 1986 [1963]. Murphy-Lawless: Reading Birth and Death ...

17 El matrimonio es normalmente virilocal y la herencia de la tierra patrilineal, salvo si faltan hijos varones. En tal caso, el vínculo patrilineal puede recrearse a través de una hija, y entonces el matrimonio será uxorilocal.

18 En el cabildo pastoral altoandino de Tumaykuri (ayllu Majapicha, mitad Majasaya, de Macha), las parteras (unquchij) son consideradas como las equivalentes femeninas de los hombres chamanes (yachaj, "sabio"). Ambos son llamados a su vocación al ser fulminados, reunidos y resucitados por el rayo (Cassandra Torrico, comunicación personal). En nuestra región de estudio, había varias parteras, tanto hombres como mujeres, pero ninguna se había iniciado de esta manera. También se busca la ayuda chamánica en los partos, y en un caso la partera trabajaba junto con su marido chamán. En general, los conocimientos y las capacidades prácticas se vinculan con la experiencia personal del parto: "ver", "saber" y "hacer" son las precondiciones epistemológicas para llegar a ser partera, y muchos conocimientos se transmiten horizontalmente entre hombres y mujeres, en lugar de concentrarse en manos de especialistas. 
do por toda la comunidad reunida. Pero sólo el fracaso de todos los otros recursos conducirían a que las parejas buscasen la ayuda de un sanitario del puesto médico local. Más aún, los grandes hospitales son muy temidos y evitados, como lugares siniestros donde las mujeres son "descuartizadas". ${ }^{19}$

Fueron seis las causas principales de mortalidad materna que se enfatizaron por los informantes: 1. Mala posición del bebé (wawa trankasqa); 2. Retención de la placenta (paris trankasqa); 3. Inversión del útero (iwakusyún); 4. Ataque por duendes comedores de sangre (sajt'ay, o sarchuwa$\left.q a y^{20}\right) ; 5$. Hemorragia post-parto (yawar apay); 6. Complicación post-parto (rekayra).

El segundo y el tercero de estos peligros están relacionados. La inversión del útero ${ }^{21}$ se vincula con la retención de la placenta, o sea, con el mal manejo de lo que la obstetricia noratlántica llama la "tercera etapa" del parto. ${ }^{22} \mathrm{El}$ cuarto y el quinto también están asociados, porque se considera que los abortos y las placentas no-bautizados se vuelven duendes, si no han sido enterrados o quemados cristianamente. Asociados con la pérdida de sangre post-parto (yawar apay), estos duendes comen la sangre de las madres parturientas. Sin embargo, hay problemas con la definición de hemorragia, porque la gente reconoce que la cantidad de sangre perdida puede variar mucho de una madre a otra: "nuestros adentros son de toda clase" (imay-

19 La alta tasa de cesáreas en los hospitales regionales sugiere que este miedo no carece de fundamento.

20 Sajt'ay posiblemente provenga de ¡saj!, una representación onomatopéyica de la acción de apuñalar; y $t$ ' $a$, el sufijo aymara que significa una acción repetida. "Puñalada repetida" se referiría, entonces, a las punzadas de dolor provocadas por los duendes. Desconocemos la etimología de sarchuwaqay.

21 De acuerdo con un testimonio, el útero (magre, del castellano "madre", o jakaña, del aymara) "sale de repente estirado" (ch'utast'amun). Cf. la frase recogida por el lexicógrafo Diego González Holguin: "chhutaycumuni o chhutaycutamuni, entrar por lo estrecho estirándose y forcejeando". González Holguín, Diego: Vocabulario de la Lengua General de Todo el Perú Llamada Lengua Qquichua o del Inca. Lima, 1989 [1608]. En el testimonio recogido en Macha, el infijo -yku-, que significa la entrada a un espacio estrecho, se reemplaza por el infijo aymara $-s u-$, reducido a $-s-$ antes del infijo de acción momentánea - $t$ ' $a$-, que significa un movimiento rápido de expansión de adentro hacia afuera (cf. Quechua -rqu-). Para la presencia de la afijación y la morfofonémica aymaras en el quechua potosino, ver Platt, Tristan: "The Sound of Light. Emergent communication through Quechua shamanic dialogue", en Howard-Malverde, Rosaleen (comp.): Creating context in Andean cultures. Oxford, 1997.

22 La prominencia dada a este problema en Macha, que produce un trauma agudo en las mujeres afectadas, contrasta con su relativa infrecuencia en las sociedades noratlánticas. Ver Silverton, Louise: The Art and Science of Midwifery. Londres, 1993 (pp. 424-5). Según Silverton, la inversión uterina es "una emergencia infrecuente que sucede en 1:20.000-25.000 nacimientos", aunque algunos autores dan una frecuencia mucho más alta de 1:2148. Las causas pueden ser la tracción inexperta sobre el cordón, la presión que se ejerce sobre un útero relajado o la retención mórbida. 
mana ukhuyuj kanchis). ${ }^{23}$ Veremos que el complejo mundo imaginario de los duendes llega mucho más allá de la situación inmediata del parto, alcanzando las profundidades de la tierra y muy atrás en el tiempo, hacia el pasado colectivo. La sexta causa se refiere a peligros similares, que siguen asediando a la madre después del parto.

Muchos peligros se originan en la naturaleza peculiarmente voraz que se atribuye al feto andino, y los peligros asociados de la placenta. El "feto agresivo" es una fuente de dolor, peligro y, a veces, muerte para su madre. Como ya he sugerido, no estaría demás hablar de la madre como si estuviese poseída por un pequeño "diablo" (Que. dyawlu), que debe exorcizarse "trayéndolo a la luz" (paqarichiy) o "vomitándolo" (wijch’uy) para "librarse" o "salvarse" (liwrakuy, salwakuy). Con el apoyo de los que la rodean, ella lucha por separarse de la criatura golosa y comedora de sangre que, junto con la placenta, se ha incrustado dentro de su vientre. Un largo proceso de desequilibrio interno se desarrolla con el aumento del calor y el estancamiento de la sangre, con los que se va "hilando" el cuerpo del bebé (una metáfora significativa, a la cual volveremos). Los retorcimientos violentos del útero deben llevarse a un punto culminante, si va a surgir la nueva vida de entre las garras de la muerte. ¿Por qué este énfasis en la agresión y voracidad del feto? ¿Cómo se entiende el desarrollo fetal, y cómo afecta este entendimiento al tratamiento del niño recién nacido?

La noción del parto como una batalla de la mujer por la vida es bien conocida entre las civilizaciones amerindias. Entre los Nawa del México Central, por ejemplo, las mujeres que morían, heróicamente, en el parto se comparaban a los hombres heroicos que morían en la batalla. Los guerreros muertos acompañaban al Sol desde el horizonte de la madrugada hasta el zénit, y desde allí era acompañado hasta el ocaso por las mujeres que habían muerto en el parto. ${ }^{24}$ En los Andes, puede observarse una complementariedad similar. En las batallas sobre los linderos, los protagonistas

23 Silverton, The Art and Science... (p. 408), revisa las críticas de la corriente definición biomédica de la hemorragia como $500 \mathrm{ml}$, indicando mucha variabilidad en la cantidad de sangre perdida. Esta variabilidad se reconoce por nuestros informantes de Macha. El énfasis sobre la especificidad del cuerpo de cada mujer, y su comportamiento distintivo durante el proceso de embarazo y parto, contrasta fuertemente con los estandarizados modelos fisiológicos que son utilizados por la moderna obstetricia biomédica, y que presuponen una semejanza básica entre todos los cuerpos parturientos, sin diferenciación.

24 Sullivan, Thelma: "Pregnancy, Childbirth and the Deification of the Women who Died in Childbirth. Texts from the Florentine Codex, Book VI, ff. 128v-143v", Estudios de cultura nahuátl VI. México, 1966. López Austin, Alfredo: "Los Temacpalitotique. Brujos, profanadores, ladrones y violadores", Estudios de cultura nahuátl VI. México, 1966. 
son hombres, mientras que las mujeres se reúnen detrás de las líneas de la batalla, cantando y bailando para animar a sus guerreros, y preparando la comida para su retorno. Durante el parto, sin embargo, los papeles se invierten. La mujer se convierte en la protagonista de una batalla para expulsar el feto agresivo, y su marido debe adoptar un papel de apoyo, cuidado y comprensión (aunque en la práctica esto depende mucho de las relaciones entre la pareja). Tanto en las batallas sobre los linderos, como en las del parto, se derrama la sangre sobre la tierra, y es devorada por las fuentes ctónicas del poder.

Las mujeres embarazadas son consideradas "no sanas" (mana sanuchu) o "enfermas" (unqusqa). La raíz unqu- significa desequilibrio corporal, y los extremos de calor o frío a veces se contrarrestan con medicinas de carácter opuesto para restaurar el balance humoral. Con el embarazo, sin embargo, el proceso de calentamiento se acentúa, porque sólo puede expulsarse el "bulto" de su cuerpo si se lleva el calor corporal de la mujer a un estado polarizado de fiebre. Unquy se refiere, entonces, tanto al embarazo como al mismo parto. De ahí que se diga que una mujer embarazada (unqusqa, "enferma"), que experimenta demora o dificultad para iniciar el parto, es "incapaz de enfermarse" (mana unqúy atinchu), y una falsa alarma se considera una situación donde la mujer "solo se pone bien otra vez" (thanirapullantaj). Las parteras, tanto hombres como mujeres, son aquéllas que saben "hacer que la mujer se enferme" [es decir, "que se ponga desequilibrada"] (unquchij), ayudando de esta manera a llevar el trabajo del parto a un climax exitoso.

\section{Ideas sobre la concepción}

Varios discursos se combinan para expresar el embarazo y el parto, cuyo examen nos proporciona una ventana sobre la manera de imaginar y concebir el desarrollo fetal en Macha. Como comúnmente sucede en los Andes, ${ }^{25}$ la fertilización se considera más probable durante la menstruación. La sangre menstrual es una parte principal de la contribución de la mujer a la sustancia fetal, y se dice que el feto es como una planta (sach'a),

25 Lestages, Françoise: Naissance et Petite Enfance dans les Andes Péruviennes. Pratique, rites, réprésentations. París, 1999. Canessa, Andrew: "Making Persons, Marking Difference. Procreation Beliefs in Highland Bolivia", en Loizos, Peter y Heady, Patrick (eds.): Conceiving Persons. Ethnographies of Procreation, Fertility and Growth. Londres, New Brunswick, N.J., 1999. 
y como tal necesita humedad para crecer. La idea de una planta que crece en el campo uterino de la mujer es una noción difundida por todo el mundo. ${ }^{26}$ Esta idea también se invoca cuando las mujeres de Macha dicen que la fertilidad individual de cada una está vinculada con una wirjina (del castellano "virgen"), que patrocina y vive en la tierra de un campo cercano, cuyo nombre secreto sólo ella sabe, y a quien ofrece libaciones. ${ }^{27}$

El lenguaje de la sangre impregna todo el proceso de gestación y del parto. Para los Andes, se ha sostenido que sólo la mujer aporta sangre, mientras que el hombre da el espíritu o soplo. ${ }^{28}$ Esta idea aristotélica se contrapesa en Macha por la distinción entre dos clases de sangre, la roja y la blanca. Se dice que, como la mujer, el hombre también tiene un útero (makri; del castellano madre), que es la sede de su semilla (muju); la infertilidad puede reflejar un fallo en el "aparato" reproductivo de cualquier miembro de la pareja. ${ }^{29} \mathrm{El}$ semen del hombre se considera una forma complementaria de sangre, que se combina con la sangre menstrual en el momento de la concepción. Se dice que la pérdida de sangre al final del embarazo conlleva la expulsión de sangre roja y blanca, y los grumos de sangre que se expulsan son considerados tanto masculinos como femeninos (grumos grumas, como lo expresaba un hombre). La idea de un útero masculino tiene ciertos ecos de la covada (trabajo de parto masculino), a lo cual volveremos.

La menstruación es considerada también fértil debido a su asociación con el ciclo lunar. La Luna, que - como hemos visto- existía antes de la salida del Sol, durante el tiempo abundantemente fértil de los Chullpa ancestrales, influye en el cuerpo de la mujer durante todo el embarazo, y el período de las lunas viejas y nuevas (wañu y urt'a) se considera como un período de fertilidad extrema o excesiva, porque se dice que en aquel momento el Sol está "cubriendo" (teniendo relaciones sexuales con) la luna. A veces se ven los Chullpa caminando por los campos bajo la luz de

26 Ver, para Europa, el estudio de Gélis, Jacques: History of Childbirth. Fertility, Pregnancy and Birth in Early Modern Europe. Londres, 1991 [1984]).

27 La idea andina de la concepción durante la menstruación se ha interpretado a veces como un mecanismo funcional para limitar el crecimiento demográfico. Por otra parte, a las niñas en Macha también se les aconseja que hagan el amor entre sus períodos menstruales, si no quieren quedarse embarazadas. La explicación debe buscarse más bien a nivel de la ideología religiosa y la etiología del crecimiento.

28 Arnold, Denise: Matrilineal Practice in a Patrilineal Setting: Ritual and Metaphors of Kinship in an Andean Ayllu. Tesis doctoral inédita. University College, Londres, 1988.

29 Se dice que la mujer puede carecer de sangre, y el hombre puede sufrir de quebración, que conduce a que salga pus ( $q^{\prime}$ iya $)$ de su pene. La alusión parece ser a sangre blanca podrida. 
la luna, como pequeños viejitos barbudos. Veremos que lo mismo sucede con la placenta y con los fetos abortados después de tres meses de embarazo, si se entierran sin ser bautizados cristianamente.

Otro discurso utilizado para expresar la concepción es el del ordeño: la mujer "ordeña las ovejas" (uwijamanta lichí ch'awanchis) y echa el cuajo dentro de la leche para producir el queso. La idea parece ser la de "ordeñar" el pene para que la semilla cuaje en el vientre de la mujer, y produzca un feto. Una sacudida de la fuente de leche produce una división en el queso, justo como el rayo que, si asusta a la mujer embarazada, puede producir un labio leporino o la división del feto en mellizos. ${ }^{30}$ Se insinúa la idea de que la gota seminal de sangre "blanca" produce la coagulación de la sangre menstrual "roja" de la mujer. La imagen del ordeño también refleja la participación activa de la mujer en el acto sexual, sin que esté pasivamente "receptiva" ante la penetración del hombre.

Como puede suponerse, entre las comunidades mineras de Potosí también se encuentran imágenes conexas con la minería y la metalurgia. La eyaculación del macho en el vientre puede compararse con el acto de echar metal derretido en un crisol o molde. ${ }^{31}$ En el siglo XIX, un tipo especial de greda pegajosa, llamada linki, se utilizaba en la Casa de la Moneda de Potosí para cubrir el punto del tubo de hierro de la fragua que se inserta en el horno, donde se funde la plata, para evitar que se fundiese con el crisol..$^{32}$ En Macha, linki es también el nombre de la grasa viscosa que cubre al bebé recién nacido. Un pellizco de este linki, sacado de los sobacos del bebé, se da a los que sufren la enfermedad de pérdida de grasa (siendo ésta una expresión elemental de la vida en los Andes), que se produce tras el asalto de unos seres vampirescos, muy temidos, que se conocen como llik'ichiris. Éstos pueden asumir la apariencia de prósperos y hospitalarios dueños de casa, que viven lejos de la comunidad de la víctima, y reciben a los viajeros incautos con muestras de generosidad. Después de dejarles dormir, insertan en su cuerpo un tubo, que se dice que les ha brindado el sacerdote, y extraen su grasa vital. Antes, esta grasa robada era utilizada por el sacerdote para

30 Para la relación entre el rayo y el labio leporino, como una forma de "gemelidad" incipiente en Macha, ver Platt: "Mirrors and Maize ..." También Lévi-Strauss, Claude: "Une préfiguration anatomique de la gemellité”, en Le Régard Éloigné. París, 1979. En los Andes, sin embargo, el modelo para el labio leporino proviene, probablemente, del camélido, y no de la lievre.

31 Bertonio, Ludovico: Vocabulario de Lengua Aymara. La Paz, 1956 [1612].

32 Ver Anónimo: Esplicación de algunas palabras provinciales, usadas en el Banco Nacional de Rescates y Casa Nacional de Moneda (1870). Biblioteca de la Universidad Mayor de San Andrés, La Paz (Colección J.R. Gutiérrez No 2339). 
hacer las velas de las iglesias; hoy, se envía a los Estados Unidos para lubricar la maquinaria que produce las monedas. ${ }^{33}$ Ambas versiones pueden verse como metáforas de tipos sucesivos de explotación económica. Pero el lin$k i$ de los recién nacidos parece más bien lubricar la salida resbalosa del bebé, asegurando que no se "pegue" a las paredes del útero. Tal greda retiene, pues, su asociación andina y/o bíblica con la creación de la vida. También se utiliza linki para modelar las figuras de los diablos fálicos o tíos, que son expresiones de energía vital que pueblan las minas y proveen al minero de mineral. ${ }^{34}$ Así, el linki se asocia con lubricación, fertilidad y fluido seminal, y su presencia viscosa, al cubrir al bebé emergente, también refleja la equivalencia percibida entre el pene y el bebé: uno entra y el otro sale. De ahí que un hombre jocosamente comparó la vagina, que envuelve al pene, con la faja utilizada para envolver al bebé recién nacido. Este aspecto fálico del feto nos recuerda la estrecha relación entre el pequeño "diablo" fetal y los "diablos" subterráneos de las minas.

Otro discurso muy poderoso sobre la gestación fetal y el parto se relaciona con la actividad de hilar y tejer, como podía esperarse de una civilización donde el tejido de fibras animales o vegetales se ha valorado tradicionalmente por encima de todos los demás materiales artísticos. La misma sangre, se dice, se convierte en grumos al torcerse como lana hilada; el bebé se forma de los hilos de sangre que se van aglutinando dentro de los tejidos carnosos del vientre materno. ${ }^{35}$ Los grumos de sangre que salen durante el parto se asemejan a "pelotas de lana" (muruq'u); la vagina, como acabamos de ver, puede compararse con un textil que envuelve al pene, y se dice que la misma faja usada para envolver al bebé contiene tantos hilos cómo el número de hijos que la mujer va a tener. ${ }^{36}$ Finalmente, todo el vientre se "tuerce" (khiwiy) mientras se contrae durante el parto, y los masajes

33 Para un análisis comparativo de las creencias andinas con respecto a estos seres predatorios (también conocidos como qharisiris, o ñak'aj), ver Molinié Fioravanti, Antoinette: "Sebo Bueno, Indio Muerto: La Estructura de una Creencia Andina", Bulletin de l'Institut Français d'Études Andines 20, No 1. Lima/París, 1991.

34 Absi, Pascale: Le Diable au Corps. Organisation Sociale et Symbolique de la Production Minière dans les Cooperatives de Potosí (Bolivie). Tesis doctoral inédita. École des Hautes Études en Sciences Sociales. París, 2001.

35 Es tentador imaginar que los hilos doblados son rojos y blancos y proceden de los grumos torcidos de la sangre blanca masculina y la sangre roja femenina, pero ningún informante explicitó esta idea. Tampoco es seguro (aunque parezca lógico) que la sangre masculina (semen o "cuajo") predomine en la estructura más muscular del feto masculino, y la sangre femenina en el cuerpo más suave del feto de la mujer.

36 Una mujer que no quería tener más hijos dijo que había dejado su faja sin terminar; otra dijo que había pedido a otra mujer, que deseaba tener hijos, que tejiera la suya. 
que se aplican para reposicionar un feto también requieren movimientos de torcer con las manos, que se comparan con el acto de torcer la lana para formar el hilo "como cuando uno está hilando". ${ }^{37}$

Pero sólo puede crearse un marco viable para la formación de la nueva persona si los grumos de sangre se ponen en movimiento por la introducción de una chispa vital. Ahora bien, la capacidad de la mujer para concebir se asocia también con su piedra local de fertilidad o kamiri. En nuestra región de estudio, ésta era un peñasco cercano, con forma humana, también llamada una huaca hembra. ${ }^{38}$ Algunos kamiris se asocian con animales —un perro, por ejemplo, significa partos frecuentes y fáciles. ${ }^{39}$ Los informantes también asociaron el kamiri con características físicas y morales, las cuales son transmitidas a la mujer y a su bebé. ${ }^{40}$

La palabra kamiri proviene de la raíz quechua kama-, modificada por el nominalizador aymara -iri: significa "infundidor de la vida", y fue adoptada en 1583 por el III Concilio de Lima para traducir la idea judeo-cristiana de un Dios "creador". Sin embargo, la filología moderna la interpreta más bien como el acto de infundir vida en arquetipos inertes, ${ }^{41}$ y el principio vital es el mismo para todas las formas de la vida orgánica. ${ }^{42}$ De ahí que la piedra kamiri sea una fuente de energía ctónica vital, que entra en el vientre de la mujer y pone en movimiento las sangres aportadas por ambos padres para formar grumos vivientes. El paralelo con las piedras de la fertilidad europeas es evidente, aunque no he oído que las mujeres se

37 La misma imagen de los grumos de sangre como fibras hiladas y dobladas se encuentra también entre los Kuna de Panamá. Ver Lévi-Strauss: "The Effectiveness of Symbols ..."

38 Wak'a; concentración sagrada de poder, generalmente un rasgo sobresaliente del paisaje. Ver Salomon, Frank y Urioste, Jorge: The Huarochiri Manuscript. A Testament of Andean Religion. Austin, 1991. También Astvaldsson, Astvaldur: "The Powers of Hard Rock: Meaning, Transformation and Continuity in Cultural Symbols in the Andes", Journal of Latin American Cultural Studies, Vol. 7, No 2. Londres, 1998. Astvaldsson, Astvaldur: Las Voces de los Wak'a. La Paz, 1997.

39 El zorro (una perra silvestre) también tiene asociaciones legendarias con la fertilidad y el parto, como veremos más abajo.

40 Por ejemplo, se considera que la facilidad o la dificultad del parto se hereda de la madre de la parturienta.

41 Taylor, Gerald: "Camay, camac et camasca dans le manuscrit quechua de Huarochiri", Journal de la Société des Américanistes, t. LXII. París, 1974-76. Una idea parecida se encuentra en el pensamiento cristiano, con la diferencia fundamental de que, aquí, el alma no procede de los antepasados, sino de Dios. Ver Bartolomé Clavero, "Delito y pecado: Noción y escala de transgresiones”, en Francisco Tomás y Valiente et. al., Sexo barroco y otras transgresiones premodernas. Madrid, 1990.

42 Incluso los metales fueron considerados en los Andes (como en Europa, cf. la obra de Agrícola) como materiales orgánicos, que crecían en las profundidades de las minas. Ver SalazarSoler, Carmen: "La divinidad de las tinieblas", Bulletin Français d'Études Andines 26 (3). Lima/París, 1997. 
deslicen por las piedras para frotar con sus vulvas esta fuente lítica de impregnación, como ocurrió en partes de Europa hasta épocas recientes. ${ }^{43}$

La vida, desde esta perspectiva, nace de las profundidades de la tierra, entre los "diablos" machos y hembras del deseo y poder genésico ${ }^{44} \mathrm{y}$ se introduce en el vientre de la mujer a través de las piedras de la fertilidad. Además, la palabra supay, propuesta por el III Concilio de Lima para traducir la idea cristiana de "diablo", tiene de hecho el significado subyacente de "alma" de un antepasado..$^{45}$ Tales traducciones imprecisas han contribuido mucho a la forma idiosincrásica de cristianismo que se ha desarrollado en los Andes. Podemos concluir, entonces, que la chispa vital del feto recién formado es un alma ancestral, que se transmite como la emanación de una piedra sagrada kamiri, y después se reencarna en un nuevo marco de sangre, que se forma dentro del vientre después de cuajar el grumo inicial mediante la introducción de la semilla del hombre (sangre blanca) en la sangre menstrual femenina.

\section{Señales del embarazo: el feto a los tres meses}

Sigamos ahora el proceso de gestación, para comprender cómo esta pequeña forma "diabólica" se desarrolla hasta alcanzar el momento de su expulsión. La primera señal del embarazo es la interrupción del ciclo menstrual, que se piensa como el bloqueo de la libre circulación de la sangre en el cuerpo de la mujer. Los que saben "leer" el pulso (llankhiris) "miran" o "leen" la sangre de la madre; dicen poder "escuchar" su voz a través de las yemas de sus dedos. Al iniciarse el embarazo, esta voz es lenta y estancada (lat'u), e indica la formación de los grumos en medio de un calor creciente. Esto se acompaña con la aparición de pecas negras (mirkha) en la cara de la mujer, vómitos (wijch'uy), y los antojos (mullphi) por ciertas comidas, especialmente lo que comen los demás. En Macha, tales antojos parecen reflejar la voracidad del feto adentro, y pueden dejar huellas sobre los hijos; si son muy intensos, incluso pueden dar lugar al malparto. Por

43 Ver Gélis: History of Childbirth ...

44 Harris: To Make the Earth Bear Fruit ... Martínez, Gabriel: "Los Dioses de los Cerros en los Andes”, Journal de la Société des Américanistes, t. LXIX. París, 1984.

45 Taylor, Gerald: "Supay", Amerindia 5. París, 1980. El carácter ambiguo del "diablo" andino, subrayado tanto en el siglo XVI por el sacerdote Bartolomé Álvarez como por los antropólogos modernos, también puede encontrarse en Europa (cf. el daimon griego), una consideración que no habría escapado a la atención de los teólogos del Renacimiento. Ver Del Pino, Fermín: "Introducción", en Álvarez, Bartolomé: De las costumbres y conversión de los indios del Perú (1588). Madrid, 1998. 
ejemplo, nos contaron de un joven que había nacido a los siete meses, después de que su madre sintiera un antojo intenso por la oca (tubérculo andino); sus ojos desarrollaron más tarde el color pardo de la oca. ${ }^{46}$

Los ojos de la madre también cambian, como se sabe en todo el mundo; pero los ojos de las mujeres andinas cambian de un modo especial. El blanco, se dice, crece hasta ser más visible que el iris, formando un contraste que se conoce como "ojos partidos" (allqa ñawi). Ahora bien, el concepto de allqa se refiere a la relación mutuamente excluyente entre los opuestos, tales como el blanco y el negro, la noche y el día, el hombre y la mujer, etc. ${ }^{47}$ Conlleva la idea de contradicción o divergencia dinámica de una frontera impermeable, sea ésta espacial o temporal, pero no la de convergencia o unión complementaria. ${ }^{48}$ En las oraciones quechuas del siglo XVI, la divinidad andrógina Wiraqucha, quien infundió la vida a los arquetipos de todas las cosas vivientes (kamay; de ahí que también se le conozca como Pachakamaq, "animador del mundo"), era invocado por los devotos "con ojos allqa", es decir, "animados", inspirados o poseídos por la divinidad. ${ }^{49}$

Allqa también se asocia, tanto con la transformación del tiempo histórico, cuando un período da lugar al siguiente (que emerge separándose de su predecesor), como con el nacimiento de un nuevo ser humano, que emerge como una entidad que se separa de su madre. ${ }^{50} \mathrm{Al}$ nivel mito-histórico, este proceso se considera a menudo como una inversión cósmica entre los mundos de afuera y de adentro (pachakuti), en cuanto que el nue-

46 Otros antojos incluyen cerdo asado y una sopa de carne de perro (alqu lawa).

47 Para una definición aymara de allqa en el siglo XVI, ver Bertonio: Vocabulario... Cf. para el quechua, González Holguín, Diego: Vocabulario de la Lengua General de Todo el Perú Llamada Lengua Qquichua o del Inca. Lima, 1989 [1608] (p. 19). “Allca, o ticlla [cf. tijra, n. 50]. Algo de dos colores, negro y blanco. Allcasillu, Un poco más que el blanco de la uña”. Para el carácter adivinatorio de la oposición blanco-y-negro, ver Cereceda, Verónica: "A partir de los colores de un pájaro", Boletín del Museo Chileno de Arte Pre-colombino, No. 4. Santiago de Chile, 1990.

48 Esto puede verse claramente en la forma verbal allqay, o ayqay, "dejar algo incompleto, o sin terminar" "apartarse".

49 Ver la oración pseudo-incaica a Wiraqucha, registrada por el neófito jesuita Joan de Santa Cruz Pachacuti Yamqui: Relación de Antigüedades deste Reyno del Perú (eds. Pierre Duviols \& César Itier). Lima-París-Cusco, 1993. En su texto y traducción, Itier (pp. 140-141) traduce allqa ñawi como "ojos nebulosos". La etnografía macha sugiere más bien que la frase fue elegida para expresar la "inspiración" o "posesión" de los devotos andinos por la divinidad. Los ojos allqa también se encuentran como un motivo frecuente en los diseños geométricos de Tiwanaku y Wari, como de otras civilizaciones andinas precolombinas, donde también pueden interpretarse como indicio de "inspiración divina", probablemente asociada con la ingestión de plantas halucinógenas.

50 La palabra tijrasqa, "invertido", "vuelto cabeza abajo", se usa para expresar tanto la inversión de los mundos superior e inferior durante una transición mitohistórica (pachakuti), como el malposicionamiento del bebé durante el embarazo. 
vo período nace del "mundo interior" (ukhupacha). Así, el nacimiento de la nueva vida desde la oscuridad interna del vientre se presenta como paralelo con la emergencia de una nueva época desde la oscuridad interna de una época anterior. Veremos que el simbolismo del contraste entre blanco y negro también se invoca después del nacimiento, para expresar y realizar la separación ritual de la madre y su crío.

A los tres meses, el feto ya muestra su naturaleza. Primero, la madre piensa poder adivinar su sexo interpretando las sensaciones que se producen en ella por sus movimientos. Un macho se mueve "aquí y allá, como un pescadito" (challwa), ${ }^{51}$ "que juega en nuestros estómagos"; mientras que la hembra se mueve más suavemente "como una nube apartándose" (phuyu), o como las olitas en la orilla de un lago; porque las hembras no se solidifican tan completamente como los machos. ${ }^{52}$ Así, el feto del macho se mueve como un pescadito plateado que se tuerce en un lago rojo de sangre femenina. Durante el embarazo la construcción social del género surge, por lo tanto, de la lectura que da la madre de sus propias sensaciones, que se interpretan como las señales de un comportamiento genérico incipiente. En otras palabras, ella misma construye (performs) el comportamiento genérico que se esperará del niño después de nacer, pretendiendo reconocerlo como un mensaje que emana de los movimientos espontáneos del feto. ${ }^{53}$ Luego, la dualidad genérica se construye como si fuera esencial, o sea, como algo inherente a las diferencias de desarrollo entre los fetos machos y hembras.

51 Los peces-gato se encuentran en los manantiales térmicos cercanos a Phutina. Se cogen por los niños, quienes desvían una parte de la corriente del agua hacia una pequeña represa, hecha de piedras, que forma una lagunita donde los peces-gato quedan atrapados. En el siglo XVI, estos peces-gato pueden haberse relacionado con los divinos peces-gato gemelos del lago Titicaca, adorados antes de la aparición milagrosa de la Virgen de Copacabana. Ver Gisbert, Teresa: "El ídolo de Copacabana, la virgen María y el mundo mítico de los Aymaras", Yachay, no. 1. Cochabamba, 1984. Bouysse-Cassagne, Thérèse: Lluvias y Cernizas. Dos Pachacuti en la historia. La Paz, 1988. Wachtel: Le rétour des ancêtres ... Los bebés recién nacidos se levantan "como peces" (piskaru jina), es decir, por sus pies o "cola". Para un análisis detallado de los peces-gato fetales entre los Dogon del África Occidental, ver Dieterlen, Germaine: "L'image du corps et les composantes de la personne chez les Dogons", en Singularités: les voies d'émergence individuelle...

52 La fuerza suave, líquida y lacustre de las mujeres, que se opone al carácter duro, pétreo y montañoso atribuido a los hombres, es bien conocida por la clasificación dual de las federaciones aymaras pre-hispánicas en uma y urqu. Ver Bouysse-Cassagne, Thérèse: La identidad aymara. La Paz, 1987.

53 Para la construcción "performativa" del género en las sociedades post-modernas del Atlántico Norte, ver Butler, Judith: Gender Trouble. Feminism and the Subversion of Identity. Londres, 1990. En Macha, la "performance" inicial consiste en las descripciones y las clasificaciones dualistas de los movimientos fetales, que son pronunciadas por la madre a los tres meses del embarazo, y sirven para atribuir a los fetos de cada sexo las características que se consideran, socialmente, como "esenciales" de cada uno. 
Mas aún, se dice que tales diferencias pueden observarse concretamente en el caso de los fetos abortados a los tres meses. Hay abortos que se llevan a cabo secretamente por las jóvenes solteras, en las quebradas que marcan los límites de la comunidad, donde los fetos pueden enterrarse sin bautizar, sin sal y sin nombre. La hembra, se dice, emerge en grumos de sangre (qulu) que todavía no se han solidificado, mientras que el macho aparece a los tres meses como "todo un hombrecito" (qharisitutapuni). La atmósfera de proscripción legal y vigilancia policial, que rodea el aborto en la Bolivia rural, la convierte en un área especialmente sensible para la investigación. ${ }^{54}$ Sin embargo, la gente se asusta mortalmente de estos "bichos" pequeños, que se conocen como q'ara wawas ("bebés desnudos"), q'ara uñas ("críos desnudos" —uña se usa comúnmente para designar a las crías de los animales) o duendes. Siguen creciendo en sus tumbas inquietas y salen en la noche, sobre todo en el período entre la luna llena y la nueva, momento en el que pueden verse bailando juntos, emitiendo una luz fantasmal (de ahí que también se les llame nina k'ara, "fuego pulsante"). Se sienten atraídos por los niños pequeños, con quienes juegan, y pueden comerlos si no se les ahuyenta con un rosario o un pedazo de hierro. Les crecen las barbas y se comportan de manera muy parecida a los Chullpa, hacia quienes parecen ir revirtiendo, lentamente, en una inversión extraña de la dirección del tiempo.

Algunos (siempre "otros", nunca los del grupo del informante) conservan y disecan estos fetos, ofreciéndoles comidas rituales para adquirir riquezas y prosperidad. Incluso se los puede ofrecer al gran cerro hambriento de Tankatanka, ${ }^{55}$ en las fronteras de la puna de Macha con el departamento de Oruro. Este cerro se dice que toma la forma de una serpiente barbuda; la misma serpiente parece personificar el carácter fálico de los fetos, a la vez peligrosos y fértiles. ${ }^{56}$ No nos sorprende que los principales devotos de Tankatanka sean - en opinión de los indios- la población mestiza en ascenso de los pueblos rurales, que a veces caen bajo la sospecha de

54 Las niñas solteras pueden romper todas las reglas del embarazo para provocar un aborto que tendrá la apariencia de un malparto, maltratándose al levantar bultos pesados, tirándose desde una altura, etc. Los abortivos incluyen el alcohol puro, una parte del panal de la abeja ladrón Lestrimelitta (tujtu pun$k u$ ) y un tinte verde químico que se vende en los mercados, además de infusiones herbales (manzanilla, romero, el cactus qhiwalli, etc.), del mismo modo que se usan para provocar las contracciones del parto.

55 También el nombre de una divinidad triple adorada entre los Charka pre-hispánicos. De Vérincourt, Virginie: Rituels et Croyances Chamaniques dans les Andes boliviennes. Les semences du foudre. París 2000.

56 Como dijo un hombre, la serpiente de Tankatanka es “¡tan gruesa como aquél bebé!” (chay wawa rakhu jina). 
tener tendencias satánicas poco escrupulosas, como una manera de explicar su mayor riqueza mercantil.

Los fetos abortados son furiosos y vengativos, porque se les ha expulsado de su cómoda morada dentro del vientre, donde podían comer sangre materna en abundancia. Ansiosos por recuperar la nutrición perdida, salen a vagar en la noche, olfateando el lugar donde puede estar dando a luz una mujer, sobre todo si el parto va acompañado por una abundante pérdida de sangre. Visitan la casa, y empiezan a comer la sangre con la mirada de sus grandes ojos fetales ${ }^{57}$ (¿una inversión mortífera de los “ojos partidos” de la embarazada?), antes de entrar por su vagina para abrirse camino hacia arriba; si llegan a su corazón (kurasun), la mujer muere. La madre es particularmente vulnerable si está sola y soñolienta; ${ }^{58}$ despierta con violentos dolores de estómago que le hacen crujir los dientes, mientras que los duendes "matan en la sangre" (yawarpi wañuchin). Pero se les puede mantener alejados con la presencia tranquilizante de varios hombres mascando coca y vigilando, y con el ordenamiento de elementos simbólicos en el umbral de la puerta: semillas de quinoa (que representan a mucha gente), ${ }^{59}$ un peine ( $\tilde{n} a j c h a$, que representa el monte espinoso, que no puede pasarse por los duendes), un espejo (que representa un "peñasco resbaloso", llusk'a qaqa), o un látigo de piel de vaca (lasu, que inspira el miedo de los cuernos de la vaca).

La creencia en los q'ara wawa muestra claramente el carácter "diabólico" que se atribuye a los fetos. En la España del siglo XVI, los duendes fueron considerados los "ángeles caídos” que ocupaban las cavernas y los pozos y estaban a cargo de las minas y de la riqueza mineral. ${ }^{60}$ Una

57 La referencia a los ojos recuerda los inmensos ojos sin párpados del feto antes de alcanzar la novena semana. Ver Wolpert, Lewis: The Triumph of the Embryo. Oxford, 1991. Inversamente, una mujer que se había dedicado a asistir a las parturientas dijo que se había vuelto ciega por haber mirado demasiada sangre.

58 El q'ara wawa andino probablemente se relaciona con el temacpalitotique de los Nawa, que usaba los brazos mutilados de las mujeres muertas en el parto para echar un hechizo de sueño e inmovilidad sobre los ocupantes de una casa, cuyos bienes y mujeres en seguida procedía a robar y violar. Ver López Austin: "Los Temacpalitotique ..."

59 Según los informantes de Macha, la quinoa era una de las comidas favoritas de los Chullpa, y, según Waman Puma, se utilizó por los Inka para hacer recuentos de la población.

60 Ver Covarrubias, Sebastián de: Tesoro de la Lengua Castellana o Española. Barcelona, 1993 [1611]. Covarrubias también vincula a los duendes con la tarasca, un monstruo con colmillos que salía en las procesiones españolas de Corpus Cristi, y también se conoce en las fiestas andinas. R.T. Zuidema sostiene que, en las procesiones de Corpus Cristi del Cusco colonial, la tarasca española encubría la serpiente-arcoiris andina (amaru) (de la cual la serpiente de Tankatanka puede ser una manifestación local). Ver Zuidema, R.T.: "De la Tarasca a Mama Huaco. La historia de un mito y rito cuzqueño", en Pierre Duviols (coord.): Religions des Andes et Langues Indigènes. Equateur-Perou-Bolivie avant et après la Conquete Espagnole. Aix-en-Provence, 1993. 
creencia similar en los duendes mineros existía en muchas otras partes de Europa ${ }^{61}$ En los Andes, también se considera a los "diablos" como los dueños de la riqueza mineral. El aborto del feto revela, pues, su verdadera naturaleza como la reencarnación de un alma muerta pagana - de hecho, los seres peligrosos que cometen el sajt'ay o sarchuwaqay se llaman a veces explícitamente almas (aquí la palabra castellana ha reemplazado a la voz quechua supay). Se reconocen claramente los riesgos de soltar del vientre a este feto diabólico antes de tiempo. ${ }^{62}$ Su hambre es similar a la de las huacas ancestrales andinas y a la de los modernos diablos mineros que, si se les priva de sus ofrendas acostumbradas, "comen" —o sea, drenan de sustancia vital-a los que han fallado en su deber de alimentarles. Igualmente, el feto abortado intenta ser el caníbal de las parturientas, mientras revierte inexorablemente a su condición originaria de Chullpa ancestral. Solo si el feto puede seguir comiendo sangre dentro del vientre, puede el alma hambrienta del antepasado crecer hasta renacer, con la posibilidad de la conversión post-natal en un pequeño cristiano viviente.

La naturaleza agresiva del feto queda así manifiesta. El proceso de gestación se caracteriza por la absorción hambrienta de la sangre de la madre, mientras sigue creciendo en tamaño y fuerzas, llevándola al borde de la muerte antes de que, finalmente, ella pueda expulsarlo en un paroxismo de calor y contorsión. Esta peligrosa lucha entre su maternidad y el feto es su mayor lucha. La voracidad del feto sólo puede ser domesticada y socializada después de realizarse ciertos ritos de separación de la madre, que se llevan a cabo antes de que se le dé el pecho y se le bautize con un nombre, como un miembro individualizado de la sociedad cristiana andina. Pasaré ahora a considerar estos ritos de separación.

\section{Conociendo el momento}

Los exámenes prenatales se llevan a cabo por un masajista (qaquri), que también puede ser una partera (unquchij) o leedor de pulsos (llankhiri). En este momento, el lenguaje de la sangre se escucha de nuevo. En que-

61 Salazar-Soler: "La divinidad de las tinieblas ..."

62 Como dijo un informante, en la forma de un refrán: “'wawastapis wañuchishan, rimuñus purishan', nishanchis" ("Decimos: 'a los bebés están matando, y los demonios están caminando"”). El incesto fue mencionado como un motivo justificado para el aborto (como lo es también según la ley boliviana). 
chua, casi cualquier proceso puede representarse fonémicamente, ${ }^{63}$ aunque el movimiento de la sangre conlleva tal confusión de los sentidos que las sensaciones y los ruidos llegan a ser casi indiferenciables. La onomatopeya quechua nos permite escuchar las palabras dichas por la sangre. Un embarazo sano, que llega a su fin, es indicado por un pulso que dice iphuj! ¡phuj! —el mismo sonido que hacen tanto la chicha (cerveza de maíz) en fermentación (con la cual se compara el líquido amniótico), como la sopa espesa calentada con tres piedras, llamada qalapari (o qalapurqa), que era una de las comidas preferidas de los Chullpa. El parto inminente se oye como ;thum! ¡thum!; mientras un vacilante y delicado it'iuj! ¡t'iuj! dice al leedor de pulsos que el parto está aún lejos.

La posición del bebé se revisa con un masaje suave, que ya se habrá hecho por la propia mujer y su marido. En caso de mala posición, la partera, hombre o mujer, puede a veces enderezar al bebé ${ }^{64}$ Untando sus manos con greda, coca mascada y mezclada con nuez moscada, o con khuru (una raíz aromática), la partera masajea, suave pero firmemente, con el movimiento de hilar ya mencionado: ambas manos frotan en sentidos inversos en torno al ombligo axial. Si la cabeza debe dirigirse hacia el cuello del útero (trichu; del castellano "trecho"), se usa un movimiento convergente, desde las costillas hacia el cuello debajo del ombligo, que se toma como el centro del cuerpo. Alternativamente, la mujer puede ser colocada en un poncho, que se sacude y se tira con movimientos precisos, e incluso puede ser lanzada al aire tres veces por dos o cuatro hombres, que agarran las esquinas del poncho (Que. thalay; en castellano "mantear"). ${ }^{65}$ También se le puede "hacer bailar" (tusuchiy), saltando, bajo la dirección de la partera, para reposicionar el "bulto" (wultu) pesado en su interior.

Si bien se supone que el momento más probable para el inicio del parto se da entre la luna llena y la nueva, existe, sin embargo, algún desacuer-

63 Para el carácter altamente motivado del signo lingüístico en quechua, ver Bruce Mannheim: The Language of the Inka since the European Invasion. Austin, 1991.

64 Una indicación de que el bebé está a un lado del vientre es la sensación de vacío en el otro. Algunas madres dijeron que habían detectado el malposicionamiento del feto por el dolor causado por el peso adicional que caía sobre un pie.

65 Algunos movimientos del thalay (manteo) parecen ser más violentos que aquél que se practica entre los Maya, descrito por Sheila Kitzinger como "meceo pélvico". Ver en Davis-Lloyd \& Sargent: Childbirth and Authoritative Knowledge. Existe una representación del manteo por cuatro chamanes cornudos, uno con un largo bastón blanco-y-negro (allqa), procedente de la Cultura Imperial Chancay de la costa peruana (1300-1532 DC). Ver la "Escena Médica" de algodón y fibra de llama perteneciente al Museo Larco Hoyle de Lima, que pude contemplar en la exhibición "Tesoros del Antiguo Perú", Museo Arqueológico, Sevilla, presentada del 8 de mayo al 12 de junio de 1999. 
do sobre el número de meses del embarazo. Las niñas se supone que requieren menos tiempo que los niños, quienes deben hacer cuajar más sustancia muscular y huesuda. De ahí que las niñas puedan nacer a los ocho meses y los niños a los nueve o incluso diez, aunque hay incertidumbre sobre qué calendario debe usarse. Una pareja dijo que contaban el tiempo en semanas de ocho días (de lunes a lunes, martes a martes, etc.), que daría un "mes" de cuatro semanas largas y de 32 días. En general, se esperan variaciones debido a la diversidad de "nuestros adentros", rechazándose nuevamente los intentos biomédicos (y, en este caso, bíblicos) de producir un modelo estandarizado del cuerpo femenino.

\section{Vomitando el feto}

Cuando "estallan las copas", ${ }^{66}$ y la sagrada "chicha" (el líquido amniótico) cae al suelo, la mujer se viste con un viejo vestido y se peina cuidadosamente mientras yace, esperando, con un fajín (wufanta) (tal como se lleva por los guerreros en las batallas) enrollado a la cintura, ${ }^{67}$ que se apretará inmediatamente después del parto para evitar que la placenta la asfixie al "flotar" (phaway) hacia arriba dentro de su cuerpo, buscando al bebé.

Tanto en las consultas pre-natales como durante el propio parto, la situación de la mujer se relaciona ritualmente con su contexto cósmico más amplio. Se echan las libaciones en las esquinas de la casa, y para las glorias (o rayos). Se establecen correspondencias armoniosas entre el vientre de la mujer como una cueva dentro de la tierra, fuente del crecimiento y del nacimiento, como también con el mundo superior, fuente de la luz y del orden cristianos, que se refractan en los cristales del nacimiento utilizados en la construcción de las ofrendas rituales (mesas). Al hacer del cuerpo de la madre el centro de un conjunto embutido de dimensiones correspondientes, se establecen las condiciones geománticas necesarias para un nacimiento seguro.

66 Wasus t'ujyay; la imagen proviene del vocabulario ceremonial de las libaciones: en ese contexto, los wasus son fuentes de madera, llenas de chicha (cerveza de maíz), a menudo con dos toros en el centro, tallados en madera. Se echan gotas de chicha sobre la tierra antes de servirse, para alimentar a las divinidades ctónicas.

67 Así sucede si las circunstancias son favorables. Pero una mujer nos contó cómo habían empezado las contracciones mientras estaba cocinando patatas en un horno de tierra (wathiya). Su marido quería que terminara de cocinar la comida, pero su hija le dijo que corriese rápidamente a casa. Al llegar, aseguró la puerta desde adentro, para que su marido no pudiera entrar, y dió a luz a solas, agarrada al lateral del catre. 
Algunos problemas pueden corregirse analógicamente al invertir el origen de la dificultad. Éstos pueden haberse ocasionado por las correspondencias negativas, producto de la negligencia. Por ejemplo, si la mujer hila durante el embarazo, el cordón puede enredarse alrededor del cuello del feto; tejer a pleno sol puede "tostar" la placenta, haciendo que se pegue a la pared uterina; alzar una carga sobre la espalda ( $q$ 'ipiy) puede torcer el cuerpo (khiwiy, palabra también usada para las contracciones), dejando al bebé malposicionado. La ceremonia de "romper el hilo" (p'itira) es una técnica para rectificar el daño. El cuerpo de la paciente se envuelve con un hilo de lana de llama, plegado a la izquierda (lluq'i q'aytu), que después se rompe para soltar la maraña u obstrucción adentro. La phishkura es otro rito de "inversión" (kuti, lit. "vuelta, retorno"), en el cual se sacrifica una oveja y se ofrece la sangre al rayo (gloria), mientras que el cuerpo de la paciente (en este caso, la parturienta) se frota con fetos de camélido (sullu) para absorber la desgracia, y luego se reducen a cenizas, que se dejan recogidas en un envoltorio ${ }^{68}$ al lado del camino, donde el mal puede pasar a un caminante demasiado curioso.

Para ayudar al parto, el proceso de cocción dentro de la mujer se acentúa por la administración de infusiones (mat'i), por fumigación ( $q$ 'ushnichiy ${ }^{69}$ ) y por vaporización (wawsi). Los humos calientes envuelven su cuerpo por dentro y por fuera, ayudando a inducir las contracciones. Una receta de fumigación consiste en hojas tostadas del árbol siempre verde llamado molle, muy utilizado en los ritos públicos para propiciar la vida y la reproducción, cuyo humo picante le resulta molesto al feto y lo hace salir rápidamente: la imagen sugiere una técnica para sacar a un animal silvestre o a un enjambre de abejas de su nido o refugio. ${ }^{70}$ Las infusiones pueden prepararse con manzanilla, romero $\mathrm{u}$ otras hierbas propiamente andinas (especialmente las hierbas etno-oxitócicas kancha lawa, wallik'iya

68 Sobre la importancia de los envoltorios en las culturas amerindias, ver Desveaux, Emmanuel: "Le Placenta ou le Double Mort du Nouveau-Né". Journal de la Société des Américanistes 84 (1). París, 1998.

69 La mujer se pone de pie, con las piernas separadas, por encima de una olla humeante de sustancias médicas encendidas.

70 "La fumigamos adentro con molle tostado. Eso pronto hace que el bebé se asquee desde adentro, pronto - molle es amargo, ¿no? ¡Eso es! hace salir inmediatamente al bebé” (mulliwan asaykunchis. ujta wawata millachimun ukhumanta, ujta - mulliqa jayaqa piru, i?. asta! wawata quchimun pacha). También: "Debe hacer un mal olor en el vapor" (wawsipi phututiykuchina [reduplicación de $t u>t i$ antes de $-y k u$-]). Una idea similar subyace probablemente en el uso de la cola de zorrino en la práctica partera nahua. Ver Sullivan: "Pregnancy, Childbirth and the Deification ..." 
y alusima $\left.^{71}\right)$, junto con miel de abejas tropicales sin aguijón y de avispas, todo hervido en alcohol de uvas (singani) o melaza. Los caldos de grasa de gallina y de huesos de res, condimentados con bayas picantes de $u l u$ pika, también se ofrecen a la parturienta. La misma partera describió otra infusión, de orina fermentada con hierbas, todo hervido con tres piedras calientes (qalapari, la comida de los Chullpa). Tres granos de trigo, de calabaza y de alusima ${ }^{72}$ se añaden al agua ya enverdecida con hoja de coca, y los humos vaporosos ayudan a hacer resbaloso al bebé. Los masajes del vientre con grasa de gallina calientan más el útero, y frotar los muslos con las deposiciones (wallpa aka) o diarrea de gallina (wallpa q'icha) también ayudan al bebé a deslizarse hacia fuera. Si el bebé está malposicionado y no puede salir, la madre debe ser sacudida o manteada nuevamente, y se dan otros masajes; un partero dijo que solía aplicar su rodilla al vientre de la mujer. Jalar las articulaciones de los dedos o traquetear el cuello hacia un lado son formas de quiropraxis que permiten liberar la tensión y el miedo (mulla). La mujer también puede ser obligada a soplar fuertemente en una botella verde, para forzar los músculos de su estómago hacia abajo e inducir contracciones.

La pérdida de sangre —un parto "húmedo"- hace más fácil el nacimiento; un parto "seco" puede doler mucho. Aunque algunas mujeres tienen partos fáciles, la mayoría sufre: hay un constante énfasis sobre el dolor. Se le puede dar para morder un suéter (chompa) de lana o una piel de animal; una parturienta dijo que había desgarrado una piel con sus dientes crujientes, haciendo el sonido iqhiij! iqhiij! Si el dolor se vuelve insoportable, la partera la anima a gritar (“'iGrita, niña, grita!”), llamando a la Madre Remedios, la compañera de San Pedro en la parroquia cercana de San Pedro de Macha, o a la Madre Guadalupe, ambas vírgenes ${ }^{73}$ patronas del parto. El marido puede unirse a ella con sus propios gritos simpatizantes. Si el bebé aún no sale, la partera o ayudante puede meter su mano en la vagina para encontrar y guiar la cabeza (lavando sus manos primero en orina antisépti-

71 Wallik’iya, cedrón (Psoralea Pubescens); alusima, espliego (Hyssopus officinalis). Estas y otras identificaciones botánicas provienen del estudio de Denise Y. Arnold y Juan de Dios Yapita (con Margarita Tito): Vocabulario aymara del parto y de la vida reproductiva de la mujer. La Paz, 1999. Este valioso libro representa otro producto, referente sobre todo al mundo aymara del Altiplano, del proyecto financiado por la DG XII.

72 "Sólo treses, pues, tres de trigo, tres de calabaza, tres de alusima. Tres, pues. Eso pronto hace resbaloso al bebé" (kinsitallataj a, trigu kinsa, sapallu luru kinsa, alusima kinsa. a kinsa. chayqa llusk'a chay ratu wawataqa chayqa).

73 Se supone que las wirjinas (del castellano "virgen") existen en las capillas cristianas, y también como formas de la Tierra Madre (Pachamama) dentro de la tierra. 
ca). Pero el peligro y la muerte están siempre presentes. Las hinchazones (punkiy, posiblemente pre-eclampsia) se reconocen como impedimentos para un parto fácil, y a veces el bebé está atrancado de lado (wawa trankas$q a$ ), la "puerta está bloqueada" y no puede salir. ${ }^{74}$ En ese caso, la mujer quizás muera, salvo si el sanitario del puesto local puede ayudar. ${ }^{75}$

Se adoptan varias posiciones para dar a luz: en cuclillas (chukusqa), sentada (tiyasqa), de pie (con el apoyo de los presentes), agarrada al lateral del catre (si se da a luz a solas), a cuatro patas (wakachasqa). El marido puede apoyar a su mujer, tomándola por la cintura desde atrás, con una partera o una pariente sentada delante para recibir el bebé; si el nacimiento se ha realizado en familia, la partera a veces puede entrar después del parto para levantar al bebé y dar cuidado post-natal a la madre. Pero se considera absurdo dar a luz echada sobre las espaldas en posición supina. Esta actitud concuerda con las críticas de la práctica corriente biomédica por las feministas, e incluso desde dentro de la misma profesión obstétrica. ${ }^{76}$

El bebé se desliza para afuera con el sonido de iphallaj!, una onomatopeya que se tradujo en el siglo XVI como "dar a luz, o el reventar de una presa de agua, de sangre o cosas similares". ${ }^{77}$ El estancamiento de la sangre se ha terminado, el dique se ha reventado, el pan ha salido del horno, y la normal circulación de la sangre de la madre puede retomar su curso.

\section{Tratamiento postnatal del bebé}

\section{Cortando el cordón}

Inmediatamente después de la expulsión del bebé, mientras aún yace en el suelo o sobre una frazada, ${ }^{78}$ la partera rápidamente aprieta el fajín alre-

74 Esto puede producirse durante el embarazo al levantar bultos pesados, torcer el cuerpo para alzar una carga o por la violencia marital.

75 En un caso, el sanitario local pudo sacar al bebé, cuando habían fallado todos los otros recursos. "Lo alzó como un pescadito, ¡sí!" Pero la gente protestó de que el sanitario no había prestado ninguna atención al fajín en torno a la cintura de la mujer, y la madre se quejó amargamente de que había usado agua fría para lavarla a ella y al bebé.

76 Ver Murphy-Lawless: Reading Birth and Death ...

77 Ver Bertonio: Vocabulario... (II:255). "phallacatha, parir o reventar el agua represada, sangre y cosas semejantes".

78 Lestages: Naissance et Petite Enfance... Lestages informa que, en Huarochiri, la madre da a luz en cuclillas, y el bebé cae de cabeza sobre una depresión en el suelo, que representa un re-nacimiento del vientre de la Tierra Madre, Pachamama. No he escuchado referencias a esta práctica en Macha, pero sí la idea de un renacimiento de un "vientre masculino" de andrajos, como veremos en seguida. 
dedor de la cintura de la mujer para evitar que la placenta "flote" (phaway), "salte" (phinkiy) o "se alce" (jijkatay) dentro del cuerpo en busca del bebé perdido, llegando así a asfixiar a la madre. Sólo entonces se corta el cordón (kururu) con un tiesto ( $k^{\prime}$ analla), a veces recogido del suelo al instante fuera de la casa. Los tiestos también se asocian con los restos arqueológicos del tiempo de los Chullpa. El cordón se ata del lado del bebé con hilo (ilu).$^{79}$ Esta parte se va a secar y caer dentro de una semana, y puede usarse en forma de polvo como un remedio para la malaria. El cuidado prioritario que se da a la madre confirma la preocupación que se siente por su seguridad, por encima de la del bebé.

Se dice que el uso del tiesto garantizará que el niño tenga siempre buena ropa; el uso de las tijeras o de una cuchilla (gilette), que ahora se ha adoptado en algunas familias, se critica por los tradicionalistas, quienes dicen que esto va a suponer ropa escasa y andrajosa. Detrás de estas creencias subyace un cuento sobre el origen del tejido, que nos proporciona una clave importante para interpretar la conceptualización del parto en Macha. Dios, se dice, dijo al zorro que ordenase a las mujeres sacar sus tejidos de las ollas, pero el zorro les dijo que pusiesen cuatro palos en el suelo para tejer. El zorro es una figura farsante ("trickster"), asociada con los orígenes de la cultura ${ }^{80} \mathrm{La}$ idea de que los tejidos debieran sacarse "cocidos" de las ollas ofrece una analogía con la emergencia del feto "hilado" del vientre caliente y húmedo de la madre. La voluntad de Dios sigue

79 Encontramos un sólo caso atípico, donde se había cortado el cordón después de la expulsión de la placenta. Esta práctica es beneficiosa para madre y bebé, y también reduce el riesgo de la retención placentaria. Ver Inch, S: Birthrights. A Parent's Guide to Modern Childbirth. Londres, 1989.

80 En un cuento, el zorro quema a sus bebés por error, convirtiéndoles en momias disecadas, después de que la perdiz ( $p$ 'isaqa) le haya dicho que los ponga al horno para darles un lindo color tostado. Luego, la perdiz, amenazada por el zorro, desparrama sal blanca y ají rojo en sus ojos después de "bailar" sobre su nariz, y escapa. Con la cocción excesiva de los hijos del zorro, la fertilidad de las sangres roja y blanca se convierte en el dolor enceguecedor de los dos condimentos.

En otro cuento, el zorro intenta bajar a la tierra desde un banquete en el cielo, hilando un cordón de paja, que es cortado por un loro con su "pico de calabaza" (mathisimi; un tiesto "natural"), dejando caer al zorro, quien grita que le tiendan una frazada (como si cayera de una vulva nutritiva). Pero cae sobre un cactus y se revienta su estómago, desparramando todas las semillas de los cultivos utilizados en la agricultura andina. En lugar de caer como bebé sobre una frazada, el zorro se encuentra pariendo violentamente las bases de la alimentación andina.

En el caso actual, el zorro oculta el arte de cocinar la lana en ollas para producir tejidos (una referencia a la gestación fetal), pero muestra a las mujeres cómo colocar cuatro palos en el suelo y tostarse al sol (con el riesgo consiguiente de quemar la placenta, justo como el zorro quemó a sus bebés en el horno). El vínculo entre los embarazos burlescos del zorro y los orígenes de la cultura nos presenta una figura a la vez trickster y prometeica, y puede subyacer en los antojos de la mujer encinta por la "sopa de carne de perro" (alqu lawa), como también la asociación de los kamiris-perro con los nacimientos rápidos y fáciles. 
gobernando la producción de seres humanos, a partir de las fibras sangrientas que se tuercen para formar grumos, mientras "cuecen" en la "olla" carnosa de sangre de la madre. Pero los recién nacidos, para vestirse decentemente como miembros de la sociedad cristiana, deben envolverse ahora en una "piel social" textil, ${ }^{81}$ que tejen sus madres de fibra de camélidos en un telar colgado de cuatro palos insertos en el suelo. La actividad social de tejer aparece, así, como una manera de hacer culturalmente visible la esencia tejida de los cuerpos biológicos, un paralelismo cuya expresión culinaria directa fue encubierta por las trampas del zorro. El uso del tiesto, metonímicamente relacionado con las ollas de los Chullpa, para cortar el cordón constituye, por lo tanto, una delimitación simbólica de la frontera convergente entre los tejidos internos ("naturales") y externos ("culturales") del cuerpo humano. De ahí que propicie una abundancia de buena ropa para el recién nacido.

Una vez cortado el cordón, algunas mujeres cuentan como después de nacer el bebé — si es varón- es levantado por los pies, y se le insulta por haber proporcionado a su madre tanto dolor y molestia: “¡Pescadito! ¡Porquería! ¡Pene desnudo ( $q$ ’ara ullu)! ¡Farsante! ¡Mira cómo hace sufrir a su madre, desde el principio!" Una mujer (que se llevaba especialmente mal con su esposo, a quien frecuentemente pegaba e insultaba) dijo, estando borracha, que había demasiados niños varones y que deberían matarse al nacer, asfixiándolos con una frazada o entre andrajos, "aunque su padre pueda enojarse".

\section{El vientre masculino hecho de andrajos}

Los andrajos, como tejidos deshechos, son inevitablemente significativos en los Andes. Después de nacer, se recoge y se limpia la sangre y la viscosidad con andrajos que se sacan de unos pantalones de bayeta (calzonas; hechos de tejido casero), pertenecientes al padre, que se rompen en ese preciso instante. La palabra aymara para estos andrajos, q'usuyllu o $q^{\prime}$ 'uchayllu, ${ }^{82}$ también se refiere a los andrajos teñidos de añil (que se dicen "negros", aunque son azul oscuro), con los que se amarran las piernas y

81 Turner, Terence: “The Social Skin”, en Cherfas, J \& Lewin, R (comps.): Not Work Alone. Londres, 1980 (págs.113-40). siglo XVI.

82 Ver Bertonio: Vocabulario..., para la importancia del q'uchayllu en la cultura aymara del 
los pies de la madre cuando, por primera vez, se levanta y sale al aire libre. En ambos casos, los andrajos "sellan" la piel, bloqueando el peligro de nuevos derrames de sangre a través de las superficies aún permeables (especialmente las de los pies) de la madre y del bebé. Pero en el caso de los andrajos del padre, la práctica parece relacionarse con la creencia en un útero paterno. Al igual que el bebé se ha nutrido en el vientre de la madre como un pedazo coagulado de tejido sangriento y caliente, así ahora se coloca dentro de un vientre paterno igualmente "andrajoso". Estos andrajos constituyen un paso intermedio entre los grumos torcidos de sangre, que "hilaron" el cuerpo del feto, y su vestimenta social, tejida de fibra de animal domesticado, con la cual se va a envolver en la sociedad andino-cristiana. La práctica tiene resonancias de la covada que necesitan ser comentadas.

Peter Rivière ha sostenido ${ }^{83}$ que la covada está diseñada para afirmar la contribución espiritual del padre al bebé, en contraste con la contribución física de la madre. Esta formulación aristotélica es inconsistente con la idea de los Macha de que es el padre quien aporta "sangre blanca" o cuajo, y con la importancia del alma ancestral, procedente de la piedra de la fertilidad, como la chispa vital del feto. Por otra parte, la idea de Malinowski de que la covada legitima el papel social del padre concuerda con la idea del vientre paterno de andrajos, que ofrece un puente entre los torcidos de hilo sangriento, que constituyen el feto en el vientre materno, y los diseños tejidos de fibra animal, que cubren a los miembros de una sociedad donde la propiedad de la tierra se define patrilateralmente. ${ }^{84} \mathrm{En}$ Macha, los andrajos sacados de unos viejos pantalones establecen la paternidad al representar el vientre del padre biológico y social. Mary Douglas ha sugerido que la covada es una manera de subrayar la confirmación del vínculo matrimonial mediante el nacimiento de los hijos. ${ }^{85}$ También en

83 Rivière, P.G.: "The couvade: a problem reborn", en Man, New Series, Vol. 9 No. 3, págs. 423-435, Londres, 1974.

84 La asociación de los andrajos con la paternidad se encuentra también en los Cuentos de Huarochiri (siglo XVI), donde el hijo de Macahuisa identifica a su padre al arrastrarse hacia un forastero vestido de andrajos, quien resulta ser la huaca Pariacaca disfrazada. Ver Salomon \& Urioste: The Huarochiri Manuscript... La divinidad aymara Tunupa —más tarde identificado con Santo Tomás o con Cristo - también reaparece en las leyendas modernas como otro viajero andrajoso, quien también es una divinidad disfrazada, que premia y castiga a la gente según su comportamiento, en una saga mítica ampliamente difundida en el Altiplano boliviano.

85 Cf. Bloch, Maurice: "Birth and the Beginning of Social Life among the Zafimaniry of Madagascar". En Göran Aijmer (comp.): Coming into Existence. Birth and Metaphors of Birth. Göthenburg, 1992. 
Macha el matrimonio es un proceso largo, construido por repetidos ritos de confirmación a lo largo de la vida, pero fortalecido sobre todo por el nacimiento de los niños. ${ }^{86}$ Criticando tales interpretaciones, Patrick Menget ofrece un análisis de la covada ${ }^{87}$ en términos del reordenamiento de universos cognáticos en el idioma de las sustancias. Esta teoría también capta un aspecto importante de la práctica en Macha. La existencia de dos vientres refleja los aportes complementarios de sustancia sangrienta por ambos padres y la transición del bebé desde el dominio interno de la madre al mundo exterior de los grupos patrilineales. Así, la mayoría de estas teorías logran captar diversos aspectos de la participación masculina en el acto de dar a luz en Macha. Por otra parte, al límite de su cobertura semántica, el concepto de covada tiende a diluirse, porque puede incluir muchas expresiones masculinas de preocupación y cuidado, que se reconocen como tales por la mujer. Esta perspectiva tiene una especial relevancia cuando se da el caso, como en Macha, de que la mujer a menudo es atendida solamente por su marido.

La madre es el recipiente hacia donde se canaliza el poder fertilizante de las almas ancestrales, que emanan de la piedra kamiri. Su propia contribución a la gestación se expresa por su relación social privilegiada con el ganado lanar, con el hilado y con el tejido; ella misma, cual camélida hembra, contribuye con los hilos sangrientos a la formación fetal. Pero la patrilateralidad y la virilocalidad determinan la herencia y el asentamiento de tierra y territorio. La contribución de cada padre a la sustancia fetal refleja, por lo tanto, una ideología de complementariedad genérica que puede dar lugar, sin embargo, al cuestionamiento y al conflicto. De ahí que a veces se diga que "crece la amargura entre las sangres" (jayachinakun yawarpura) dentro del feto o del individuo, reflejando una tensión entre la contribución materna y paterna a su ser físico. En el caso del feto, la división efectiva de las sangres puede producirse por un rayo poco después de la concepción, dando como resultado el nacimiento de mellizos. ${ }^{88} \mathrm{La}$ tensión entre los "vientres" materno y paterno también expresa la tensión entre los parientes de la madre y los del padre, en tanto dadores y tomadores de mujeres. ${ }^{89}$

86 Platt: "Mirrors and Maize ..."

87 Menget, Patrick: "Temps du naître, temps d'être: le couvade", en Izard, M \& Smith, P (comps.): La fonction symbolique: essais d'anthropologie. París, 1979.

88 Aquí, se supone que el relámpago o "padre" (tata) se ha equivocado (pantan); los mellizos, por lo tanto, se consideran como ocurrencias anormales y "monstruosas".

89 Ver Harris: To Make the Earth Bear Fruit ... 


\section{Del canibalismo fetal a la lactancia}

Renacido del vientre de andrajos paterno, el bebé aún tiene huellas de sangre, que luego se lavan en una fuente de orina espumosa proporcionada por todos los adultos presentes. La orina es un antiséptico que sale por los orificios inferiores del cuerpo, igual que la sangre reproductiva. ${ }^{90}$ Neutraliza y limpia al bebé en un baño amarillo y salado, que constituye un "bautismo" ctónico, anterior al bautismo cristiano de sal blanca con agua, que se administrará pocos días después.

El bebé está ahora en un estado liminal entre el vientre y la sociedad, y mientras no haya pasado por esta etapa no se le da el pecho. Durante dos o tres días debe prepararse para la lactancia, recibiendo primero unas gotas de orina sobre un estropajo de lana, o tres cucharaditas de la misma, seguida a veces por gotas de infusión o chocolate. Con la aplicación de la orina, tanto dentro como fuera del cuerpo del bebé, se intenta parar la pérdida de sangre. Madre e hijo están aún imperfectamente separados, y la sangre puede brotar por la superficie de sus pieles en cualquier momento. El tratamiento con orina produce un efecto de curtido; se dice que, de otro modo, los pies del niño podrían abrirse más tarde, al cruzar agua fría y turbia (all$p i)$, porque la piel seguirá aún tierna y fácil de diluirse. ${ }^{91}$

Pero la postergación del pecho tiene otro propósito muy importante. Funciona para romper el hambre voraz del feto, y colocarlo bajo la disciplina de la práctica nutricional humana. Esto se confirma cuando preguntamos a una madre si conocía el valor del calostro (kurta). "Sí, eso es muy bueno", contestó, "es demasiado bueno!

"No, ya no le hagan amamantar ese calostro, jordeñen eso! para que no lo coma así, si llegara a ser hombre, comerá, mucho comerá, y ¡será una vergüenza para sus padres! ¡Ordeñen esa leche [el calostro] directamente, si va a llegar a ser un hombre!”

“mana, kay kurtataqa ama ñuñchiychisñachu, ;ch'awarpaychis! mana mikhunanpaj ajina, runapis kanman, mikhunqa askha mikhunqa, tatanta mamanta qhawarachinqa, i si runapis kanman, ;chay lichita ch'awarpaypuni!"

El pensamiento está claro: la voracidad fetal no se considera social y debe cortarse y controlarse, como parte del rito de separación del bebé

90 Es posible que la orina se relacione con las aguas termales volcánicas, aunque el agua volcánica es un tema poco estudiado en los Andes.Ver, sin embargo, Bouysse-Cassagne, Lluvias y Cenizas ...

91 El resultante "talón partido" (k’akalli) se cura con grasa derretida en agua caliente. 
del cuerpo de su madre, que es asimismo un rito de entrada a la sociedad cristiana. Sólo así sabrá "aguantar" (muchuy) como adulto los períodos de hambruna, y no mostrarse tan goloso como para avergonzar a sus padres por su mala crianza.

\section{Envolviendo al guerrero y a la pastora}

Después de lavado, se envuelve al bebé en pañales (akawara) y luego en una honda (warak'a), un artefacto hecho de tejido denso, con un diseño simétrico en blanco y negro, cuyo simbolismo durante las batallas sobre los linderos se vincula con la idea de allqa.$^{92}$ Envolviéndolo en una honda, el niño será un buen guerrero, y puede añadirse una piedrita, colocada en su pequeño puño, con la cual cargar la honda y darle una "mano de piedra" (rumi maki; un nombre que también se da a los líderes guerreros en los Andes). Si el bebé es una niña, se busca garantizar con la honda su habilidad como pastora. Nuevamente, la propiedad masculina de la tierra y los barbechos, heredados patrilinealmente, se vincula con la capacidad de los hombres de proteger las fronteras territoriales; mientras que las niñas y las mujeres se vinculan con los animales que formarán parte de su dote y darán la lana con la cual tejerán la "piel social" de sus familias.

La forma del bebé se vuelve rígida, finalmente, al envolverlo con una faja (waltha chumpi), transformándolo en una pequeña y tiesa momia de fertilidad, que recuerda la forma inerte del Chullpa ancestral al que reencarna. Los restos chullpa, envueltos en textiles, eran colocados en posición fetal en sus tumbas de adobe, como si esperaran el renacimiento. ${ }^{93} \mathrm{Al}$ nacer, sin embargo, el feto se estira, y después se envuelve firmemente, llegando a ser tan rígido como el pene que inicialmente lo "cuajó" dentro de la sangre menstrual de la madre. Con su salida el feto invierte el movimiento penetrante del pene, convirtiéndose así en su expresión simbólica complementaria. De tal manera que al ser transferido desde el vientre de andrajos paterno a la honda, y luego envuelto en la "vagina" social (es decir, tejida) de la madre (la waltha chumpi), el bebé se contrapone al falo paterno, al mismo tiempo que es envuelto y recibe leche (en lugar de ser ordeñado) de su madre. ${ }^{94}$

92 Para el simbolismo oposicional del blanco-y-negro en la honda aymara o paqui korahua del siglo XVI, ver Platt, Tristan: "Pensamiento político aymara", en Xavier Albó (comp.): Raíces de América. El Mundo Aymara. Barcelona, 1988.

93 Cerca de Puno (Perú), existen chullpas (tumbas funerarias ancestrales) que tienen formas explícitamente fálicas. Ver Kauffmann Doig, Federico: Comportamiento Sexual en el Antiguo Perú. Lima, 1978.

94 Ver Lestages: Naissance et Petit Enfance ... 


\section{El bautismo doméstico cristiano}

La etapa final que lleva al bebé hacia la sociedad cristiana consiste en rociarle con sal y agua, y darle un nombre. Antes de recibir su nombre es kampa, un monito mudo y anónimo. ${ }^{95}$ El nombre cristiano se extrae del almanaque Bristol, que comúnmente circula en el campo; tradicionalmente, corresponde al santo del día en el que nació el bebé. El nombre se da con la fórmula "que sea este nombre" ('kay suti kachun' nispa), y la gente reza tres veces en latín las oraciones que mejor conoce (Pater Noster, Dominus Te Salve, Ave María, Gloria, etc.), mientras se hace la señal de la cruz sobre el bebé con agua salada. Este bautismo doméstico se lleva a cabo dos o tres días después del nacimiento, y antes que cualquier bautismo eclesiástico. Está así completa la transición de "diablo" a ser humano (es decir, cristiano), un proceso que se inició al momento de nacer, envolviéndolo en los andrajos del padre y dándole un "bautismo pre-cristiano" con orina amarilla y salada.

La amplia gama de nombres que se encuentran en el almanaque (uno o dos para cada sexo en cada día del año), y pueden ser usados durante el bautismo, debe contrastarse con los muy pocos nombres atribuidos a los diablos - Jorge y Lucas son los más comunes- y con los dos usados por las parejas antiguas de los Chullpa, quienes en los cuentos se llaman, simplemente, Mariano y María (cóndor macho y rana femenina, expresiones de los cerros y del agua). La simple dualidad genérica de los Chullpa coincide con la dualidad genérica anunciada a los tres meses por los movimientos del feto en el vientre. El grado de individuación logrado mediante el bautismo, que hoy combina el nombre del santo y el apellido del padre, es mucho mayor que los dos nombres genéricos que se atribuyen a los diablos y a los antepasados chullpa. ${ }^{96} \mathrm{La}$ transferencia del bebé, concebido bajo la influencia de la luna, al reino solar de "este mundo" (kay pacha) se logra, pues, como un proceso de individuación y especificación onomástica de la nueva persona social, realizado mediante el bautismo cristiano del feto pagano, anónimo y hambriento, que acaba de nacer.

95 La forma castellanizada camba se usa, hoy en día, para caracterizar a los habitantes de los llanos orientales de Bolivia, que no saben hablar quechua. Los monos también aparecen con los "diablos" durante procesiones festivas. Entre los Laymi vecinos, los bebés pre-bautismales se llaman moro, una clara referencia a su condición de "pre-conversos". Ver Harris: To Make the Earth Bear Fruit ...

96 Para las propiedades clasificatorias de los nombres propios, ver Lévi-Strauss, Claude: El Pensamiento Salvaje. Barcelona, 1985. Para una fase transicional entre las prácticas de nombrar precolombinas y las cristianas, en el vecino pueblo de Aullagas (Lake Poopó) a fines del siglo XVI, ver Álvarez: De las costumbres y conversión ... 


\section{El sacrificio de la placenta}

Volvamos ahora al destino del compañero placentario del feto. Después de cortar el cordón, el cabo de la placenta se ata con un hilo doblado de lana roja, que después se amarra al dedo gordo del pie izquierdo de la mujer. Esto podría verse como un medio de dotar a la mujer de su propia agencia, en cuanto que le permite ejercer su propia tracción controlada sobre la placenta para ayudarla a separarse de la pared uterina; sin embargo, una tracción demasiado violenta puede provocar hemorragia e incluso la inversión del útero, desenlaces ambos muy temidos. ${ }^{97}$

Según los informantes, las placentas pueden salir casi al mismo tiempo que el bebé, o pueden tardar hasta veinticuatro horas. La norma obstétrica de esperar media hora antes de administrar las inyecciones oxitócicas presupone una estandarización del cuerpo de las mujeres que se rechaza en Macha, donde, como hemos visto, "nuestros adentros son de toda clase". La posición adoptada para esperar la placenta también varía, pero la mayoría declararon que preferían quedarse winkusqa, o sea, en la posición en la que cada una se sentía más a gusto. ${ }^{98}$

La retención de la placenta se considera uno de los principales peligros del parto, y se asocia con el cocinar sobre el fogón o, sobre todo, con el tejer al sol: el calor sobre las espaldas de la mujer hace que la placenta se pegue a la pared uterina, como la comida que se quema en una olla o sartén. La situación puede tratarse amarrando una cataplasma de maíz hervido (mut'i) a las espaldas de la mujer: en quechua, la palabra qhirqhirchiy significa "hervir", donde el sonido del maíz hirviente se representa fonémicamente como iqhir! iqhir! El efecto analógico transfiere la separabilidad de los granos en el agua a la placenta dentro de la "olla" uterina, al mismo tiempo que restaura la humedad del "tejido" de sangre y grumos quemado. Otra técnica para obligar a la mujer a expulsar la placenta consiste en hacer que atore hasta la garganta una botella verde: así se baja el diafragma y se produce una contracción. Si falla todo lo demás, algunas parteras meten un cuchillo dentro del útero (lavando primero sus manos en orina) y extraen la placenta en pedazos.

97 El útero invertido puede corregirse al suspender a la mujer cabeza abajo desde una viga del techo (“¡no te muevas, mi niña!” dice la partera) y empujar el útero hacia adentro con el puño, después de lavar las manos en orina. Tal práctica es un equivalente rústico del tratamiento recomendado por las parteras noratlánticas, que consiste en conectar una ducha salina a la vagina, para que por la ley de la gravedad baje el líquido antiséptico, y después empujar el útero hacia adentro con el puño. Ver Silverton: The Art and Science ...

98 Agradezco a Cassandra Torrico esta interpretación de winkusqa. 
Después del nacimiento, la placenta se trata al principio de manera parecida al bebé: se envuelve en harapos y se mantiene caliente cerca de su madre. Si se deja enfriar, la madre o el bebé pueden sufrir un dolor de estómago. Esta interdependencia entre los tres inmediatamente después del parto refleja el grado incompleto de separación que se ha logrado. Aunque no se le llama explícitamente "mellizo" del bebé, la placenta parece ser tratada como su equivalente simpático. Pasados tres días, debe ser desechada correctamente, para que no se vuelva duende o q'ara wawa, como los fetos abortados. Se entierra entera, rociada con agua salada y acompañada con platos de comida, o se reduce a cenizas, con rescoldo de estiércol animal, antes de enterrarla. Dicho entierro se hace unas veces en el campo, otras debajo del umbral de la casa, donde los innumerables pies que lo pisan aseguran que no podrá salir para amenazar a la familia. ${ }^{99}$

No he encontrado ninguna evidencia de que, hoy en día, se coma la placenta por las madres de Macha, algo que fue bastante común en Europa ${ }^{100}$ donde en algunos casos se sigue practicando en la actualidad. Sin embargo, el consumo de la placenta parece haber sido parte de las prácticas de parto en el siglo XVI, y un breve comentario sobre este punto aclarará una importante diferencia entre las prácticas modernas y las pre-hispánicas. El lexicógrafo jesuita del aymara Ludovico Bertonio anotó, respecto a los Lupaqa de las orillas del lago Titicaca en el siglo XVI, lo siguiente:

“Tienen otra costumbre muy puerca y bárbara, y es que después del parto la muger come un poco de las pares, mandándoselo el hechizero, para librarse de enfermedades:

“cchihua mankamasa yocachasitathà mankantiritha". ${ }^{101}$

Ahora bien, la práctica Lupaqa del siglo XVI es probablemente parte de un conjunto más generalizado de creencias. Es probable que, en la práctica registrada por Bertonio, la placenta fuera considerada como el doble o "mellizo" del bebé, de la cual la mayor parte era ofrecida por el "hechicero" a una divinidad ctónica, después de asignar un bocado a la madre. Tal

99 La preocupación que sienten las mujeres después de dar a luz en el hospital debe relacionarse con el miedo a que las placentas puedan volverse q'ara wawa. Para un síndrome similar en la Turquía islámica, ver Gokalp: "Le Placenta ..."

100 Gélis: History of Childbirth ...

101 Bertonio, Ludovico: Advertencias (p. 252). Agradezco a Ivan Tavel, de la Universidad Católica de Cochabamba (Bolivia), por haber llamado mi atención sobre este texto, que él está preparando para una nueva edición. 
sacrificio de la placenta refleja un tratamiento común que se da a los mellizos en varias sociedades amerindias, donde se mata a uno de ellos, mientras que al otro se le permite vivir. Esta práctica, documentada hoy para los Bororo de la cuenca amazónica (Bolivia), ${ }^{102}$ también puede encontrarse en los mitos quechua de la colonia temprana recogidos en Huarochiri. ${ }^{103}$ Aquí, durante el período de sujeción al dios costero del fuego, Wallallu Qarwinchu, las mujeres daban a luz solamente mellizos, a uno de los cuales se le permitía sobrevivir, mientras que el otro era devorado por el dios del fuego. Es lícito suponer que, en este mito, el mellizo sacrificado era, en realidad, la placenta del bebé que se dejaba vivir. También parece existir una relación histórica, aún por investigar, entre el mito de Wallallu Qarwinchu y el consumo, hoy en día, de los fetos disecados por la hambrienta y fálica serpiente del cerro Tankatanka.

Así, pues, la práctica moderna es probablemente el resultado de la extirpación de idolatrías llevada a cabo por la Iglesia en los siglos XVI y XVII; antes, existía una aproximación comensal ("canibalística") al sacrificio placentario. Sin embargo, un resto del canibalismo placentario puede encontrarse todavía hoy, bajo una forma cristianizada, durante las ceremonias que acompañan a la celebración de Todos Santos y Día de Difuntos. Para esa ocasión, las almas de los muertos se representan como "bebés de pan" (t'anta wawas), pequeñas imágenes hechas de masa de pan y horneadas, que se colocan sobre la tumba en el cementerio, y después se comen por los amigos y la familia del muerto. ${ }^{104}$

\section{El cuidado postnatal de la madre}

La madre ha sido llevada hasta los confines de la muerte; pero, si ha triunfado en su batalla cósmica para expulsar el feto, debe ser traído de nuevo a la vida cotidiana. La hemorragia postpartum (yawar apay) se considera el principal peligro en esta etapa. Algunas madres se quedan en la cama durante una semana y a veces un mes, mientras que otras dicen que se levantan tras un par de días, e incluso de inmediato. El coraje femenino y la "dureza" de la mujer (wapu; del castellano "guapo") no sólo se mode-

102 Crocker, Christopher: Vital Souls. Bororo Cosmology, Natural Symbolism and Shamanism. University of Arizona Press, 1985.

103 Salomon y Urioste: The Huarochiri Manuscript ...

104 Cf.Gélis: History of Childbirth ..., para una costumbre similar en Europa. 
lan sobre la valentía de los hombres en sus batallas; ${ }^{105}$ es una calidad compartida por ambos sexos, cada uno en sus propias esferas de lucha.

Después del nacimiento, la madre se lava con agua caliente, y se le da un caldo de huesos también caliente. ${ }^{106}$ Pueden administrarse infusiones de una hierba con hojas afiladas (siwinqa; una variedad de cortaderia) para hacer "cortes" internos y asegurar que toda la sangre salga; mientras que la resina de $q^{\prime} u w a^{107}$ ayuda a congelar un brote excesivo de sangre, que podría atraer la atención fatal de los duendes. La administración de hollín (qhisi$\mathrm{ma}$ ), picante y negro, también ayuda a contener el flujo excesivo de sangre. La madre, aunque ya se ha librado del bebé, está aún en un estado muy vulnerable. Cuando quiere lavarse las manos, debe hacerlo con agua donde se ha puesto a remojo el chuño (patata disecada), que elimina la calidad "fresca" del agua pura. El chuño es "caliente", y se dice que la mujer debe evitar toda comida "fresca", como por ejemplo la patata y la carne de llama y cabra. Hay algo muy claro, y es que, cuando la mujer sale al aire libre por primera vez, sigue estando bajo el riesgo de los duendes. Aún está "abierta" y, por lo tanto, sujeta a la amenaza del frío; así, un viento chullpa podría soplar hacia sus adentros y provocarle la enfermedad de los Chullpa (chullpa unquy o chullchu unquy), una sensación de debilidad y fatiga que paraliza a la víctima. El retorno de la mujer al equilibrio humoral debe lograrse paulatinamente, mediante una dieta cuidadosa y nutritiva que, en un inicio, excluye las comidas frescas.

Antes de salir de casa, la mujer debe amarrarse los pies con andrajos teñidos, sacados de un viejo vestido (aymilla). Se trata de los "harapos negros" (yana q'uchayllu), teñidos de añil, ya mencionados, y que deben distinguirse del q'uchayllu sacado de los pantalones del padre. Puesto que la madre post-partum es susceptible de desangrarse por los pies (igual que el bebé, durante el resto de su vida, si no se lava con orina amarilla), debe amarrarse bien las piernas, desde la pantorrilla para abajo, y frotarse el puente del pie con grasa de gallina y romero, amarrándose la pomada en continuo contacto con los andrajos.

105 Sin embargo, las mujeres solteras también suelen pelear, entre ellas mismas, durante las batallas rituales o tinku, que siguen celebrándose en Macha. Para el tinku, ver Platt, Tristan: Los guerreros de Cristo. Cofradías, misa solar y guerra regenerativa en una doctrina surandina (siglos XVIIIXX). La Paz, 1996. También Platt, "Pensamiento político aymara ..."

$106 \mathrm{El}$ agua fría que se usa hoy en los hospitales es otro motivo de queja para aquellas mujeres que se encuentran internadas.

107 El incienso de q'uwa se ofrece a las divinidades ctónicas del "mundo inferior" o "interior" (ura parti, o ukhu pacha); el copal y la mirra se ofrecen más bien a las divinidades del "mundo superior" (pata parti, o janaj pacha). 


\section{Los colores del parto}

Hasta aquí, he venido mencionando la presencia de colores específicos que "tiñen" diferentes aspectos del proceso del parto. Tal vez sea útil resumir ahora las dos secuencias de contrastes de color, que organizan y vuelven significativas estas ocurrencias cromáticas aparentemente inconexas. Conviene observar que cada etapa y acción sucede bajo la irradiación de los diferentes colores del arcoiris (kuyrami), símbolo de la belleza, de la seducción y del peligro, ${ }^{108}$ que articula los diferentes aspectos del parto. Esta secuencia tonal da un significado perceptivo a las relaciones y sensaciones que afectan a la madre y al feto, desde la concepción hasta la separación post-natal.

Comencemos por los ojos blancos y negros (allqa) de la mujer embarazada. Como hemos visto, así eran los ojos de los devotos del dios andrógino Wiraqucha. Hoy, en Macha, cuando una mujer queda encinta, sus "ojos partidos" indican el movimiento de gestación iniciado dentro de su vientre, infundido con vida ancestral por la piedra kamiri. Pero ese mismo binomio puede verse, también, al final del proceso, donde el bautizo del bebé con sal blanca contrasta con los "andrajos negros" que protegen los pies de la madre mientras vuelve a la vida normal. Es como si este contraste que, en los ojos de la madre, anunciaba la formación incipiente de una nueva vida, terminara confirmando la separación exitosa del bebé, mediante la distancia física y conceptual entre la frente salada del infante bautizado y las piernas ennegrecidas de la madre.

El patrón allqa del blanco-y-negro, como principio de fecundidad, suerte y divergencia dinámica entre principios contradictorios, está ampliamente difundido en la cultura andina. ${ }^{109}$ Las piedras blancas y negras también expresaban ideas de deuda y crédito en el aymara del siglo XVI, y en otra parte he analizado su uso en las hondas de diseño blanco-y-negro para "liquidar las cuentas" entre grupos guerreros. ${ }^{110}$ Rénard-Casewitz ha analizado el contraste entre la piedra negra de la brujería y el cristal blanco del chamanismo entre los Matsigüenga del Amazonas. ${ }^{111}$ La importancia del cuarzo en el chamanismo andino del siglo XVI puede verse en los cuentos

\footnotetext{
108 Cereceda, Verónica: “Aproximaciones a una estética aymara”, en Albó (comp.): El Mundo Aymara ...

109 Cereceda: "A partir de los colores ..."

110 Platt: "Pensamiento político aymara ..."

111 Rénard-Casewitz, France-Marie. Le Banquet Masqué. Une Mythologie de l'Étranger. L’Étranger chez les Indiens Matsiguenga. París, 1991.
} 
quechuas de Huarochiri; ${ }^{112}$ mientras que, en el Potosí moderno, la sal (kachi), cuyo nombre ritual es "cuarzo" (qhispi), ha ocupado el lugar del cristal chamánico. La sal es la sustancia cristalina que refracta la luz, colocando al niño bajo el poder chamánico del sacerdote católico, que sabe la palabra de Dios. ${ }^{113}$ De hecho, en las ceremonias que propician un buen parto aún se emplea una piedra de cristal (qhispi rumi). Y las minas de sal son las únicas que caen bajo los auspicios de la "señora cristalina", qhispi siñu$r a$, una forma de la virgen cristiana; mientras que todas las otras minas pertenecen a los "diablos" ancestrales y a las fuerzas oscuras del mundo interior (ukhupacha), ocupando así la posición de la piedra negra de la brujería amazónica.

Las sangres blanca y roja son las sustancias más básicas del crecimiento fetal, siendo la blanca la semilla del hombre (que da lugar a la grasa lubricante llamada linki) y la roja la sangre menstrual de la mujer. Infundidos con vida ancestral por la piedra kamiri, estos componentes macho y hembra de la sustancia fetal se entretejen como hilos torcidos en una sola entidad. En los siglos XV y XVI, se daba la misma relación al nivel político de la confederación de los Charka, donde los señores de los Charka Rojo y Blanco también estaban vinculados por un complejo conjunto de visitas, contravisitas e intercambios ceremoniales. Los componentes y los procesos de la gestación del bebé recuerdan, al nivel del feto, las características de la antigua confederación en cuyo territorio ha nacido.

El verde es el color del molle, el árbol siempre verde, símbolo de la vida perenne en toda la región potosina. Sus amplias ramas dan una abundante sombra en los valles y lugares de descanso para los viajeros, cansados de caminar por los senderos pedregosos bajo el ardiente sol altoandino. Ramilletes de molle se llevan hasta las tierras altas para ser utilizados en la medicina y el ritual. Coberturas verdes de molle se colocan sobre las mesas ceremoniales y sobre los animales sacrificados, y se ponen en los sombreros como adorno. Son la expresión regional más vívida de la fertilidad reproductiva, y ofrecen el color paradigmático de la nueva vida. La hoja de coca se usa también para teñir de verde las infusiones. Y el tinte químico utilizado como abortivo también es verde, porque éste es el color del parto (aunque sea prematuro), como también lo es la botella verde donde sopla la mujer para producir las contracciones que expulsarán tanto al

112 Salomon y Urioste: The Huarochiri Manuscript ...

113 Para el sacerdote como chamán cristiano, ver Platt, Tristan: "Writing, shamanism and identity; or, voices from Abya-Yala", History Workshop Journal 34. Oxford University Press, 1992. 
bebé como a la placenta. El verde se asocia, por lo tanto, con la producción y la conservación de la vida terrestre y húmeda, contra la disecación mortífera con la que amenaza el fuego solar.

La orina amarilla corta el flujo de sangre roja, mientras finaliza la cocción del bebé. Constituye un bautizo ctónico, procedente de los orificios inferiores del cuerpo, antes de la transición al blanco cristalino del bautizo por la sal. En cuanto excremento corporal es parte de la cultura fertilizante de los poderes del mundo interno. Baña al bebé por dentro y por fuera, disolviendo las huellas de sangre mientras curte la piel. Es el color de la transición desde la sangre roja hacia la sal y la leche blancas, y como tal marca la socialización inminente del feto ctónico en la sociedad cristiana.

Es llamativa la coherencia del simbolismo cromático de las diferentes etapas del parto. Las transiciones perceptivas, enmarcadas por la oposición allqa, expresan cómo la madre y el bebé, que ocupan posiciones opuestas al principio del embarazo, van invirtiéndolas durante el embarazo y el parto. El bebé empieza como el negro telúrico de los ojos allqa de la madre recién encinta, ella misma todavía ubicada en la luz blanca del mundo solar cristiano. La transición del bebé, formado de sangres blanca y roja que se ponen en movimiento con el aliento de la piedra, desde la sangre roja nutricional, por vía de la orina amarilla, hacia lo blanco de la sal y de la leche materna se complementa con la transición de la madre desde lo rojo de la sangre menstrual estancada, por vía del verde del parto, hacia el q'uchayllu y el hollín negros, que curten su piel y purgan sus interiores de un exceso de sangre. Así pues, las secuencias son: Negro > Rojo/Blanco > Amarillo > Blanco (bebé); y Blanco > Rojo/Rojo > Verde > Azul/Negro (madre). Dichas secuencias expresan la una el movimiento del feto desde el mundo genésico de los poderes telúricos extra-sociales hacia la cultura humana y cristiana, y la otra el movimiento de la madre desde la posición cristiana hacia el negro de la tierra interior desde donde surge la nueva vida. El blanco-negro (allqa), que al principio se concentraba en los ojos de la madre embarazada, termina expresando la divergencia dinámica y la separación del bebé del vientre materno. En este sentido, todas las transiciones cromáticas proporcionan una estructura perceptiva para el proceso de dar a luz, que también puede contribuir a nuestra comprensión de los significados propiciatorios de las combinaciones de colores en los textiles andinos y, más ampliamente, al estudio de la óptica andina. ${ }^{114}$

114 Cereceda: "Aproximaciones ..." 


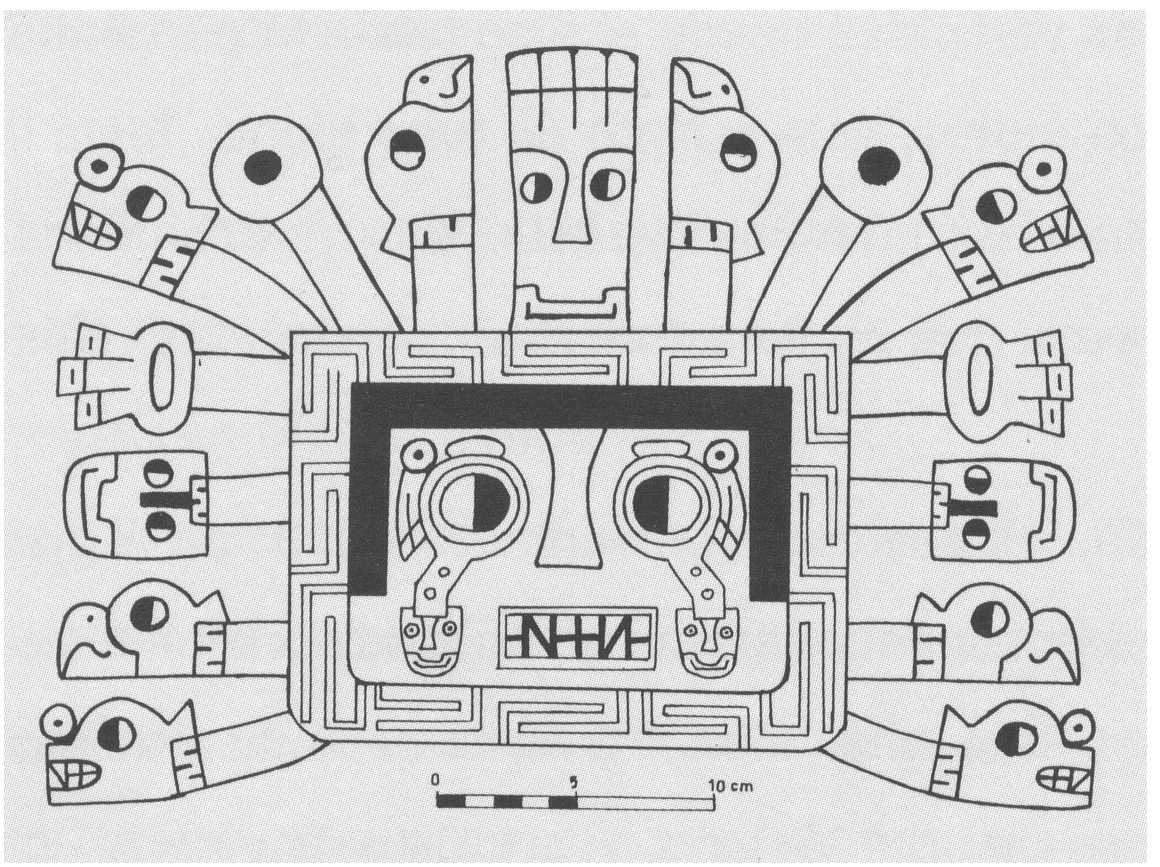

Ojos partidos (allqa) en una cabeza del dios de las varas (Cultura Wari)

Volvamos, pues, a los ojos de los devotos del Wiraqucha andrógino, el invisible infundidor de la vida en los arquetipos inertes y poseedor de sus devotos, ojos que comparten diversos seres representados en los materiales arqueológicos, y que, hasta hoy, son también los ojos de todas las mujeres embarazadas. El movimiento dinámico de allqa es el concepto clave en este paisaje imaginativo, tanto de la reproducción humana como de las transiciones históricas. El feto agresivo se ha desplazado desde las tinieblas del interior de la tierra, que son también las del vientre de la madre, y de las energías oscuras de los Chullpa, gobernados por la Luna, hacia la leche blanca y la sal cristalina del bautizo en el mundo exterior cristiano, gobernado por el Sol. Al mismo tiempo, la madre ha pasado desde la posición de un miembro del rebaño cristiano-solar hacia la condición de caverna oscura, donde se gestan las fuerzas del futuro. Lo oscuro interior ha surgido a la luz exterior y se ha separado como lo blanco de lo negro, mientras que la mujer ha debido situarse en el papel del mundo interior (ukhupacha), que 
le permite expulsar el feto pagano como si fuera hacia un nuevo período mito-histórico cristiano. Mientras tanto, el allqa permanece, en diferentes configuraciones, para enmarcar la estructura cósmica y adivinatoria de "este mundo" (kay pacha) donde vivimos, nutridos por los poderes peligrosos de ambos extremos antagónicos. ${ }^{115}$ El retorno de la madre a la vida normal de la comunidad pone fin y echa el telón a una dramática representación fisio-cósmica, que ha realizado las transformaciones del universo uterino en aras de la emergencia de una nueva vida y un nuevo tiempo.

\section{Reorientaciones}

Hemos seguido la trayectoria del embrión en Macha, desde el momento de la concepción, a través del proceso de gestación, hasta la expulsión del feto mediante el parto y, unos días después, su bautizo doméstico informal como bebé cristiano (wawa) con sal cristalina y el nombre que le otorga su identidad social. Ha empezado, pues, la pertenencia del infante a la sociedad cristiana andina, aunque le esperan muchos otros ritos de pasaje antes de poder tomar su lugar entre los mayores de la comunidad. Al replicar la historia de la sociedad nativa andina, la gestación de cada bebé da realidad a las ideas indígenas sobre su propia "otredad", como una población de perpetuos conversos andinos.

Esta analogía histórica se construye a partir de variados y dispersos elementos y discursos, que son los que también proporcionan a la mujer los recursos imaginativos para sentir, interpretar y reaccionar fisiológicamente frente a los cambios vitales, pero peligrosos y a veces dolorosos, que suceden dentro de su cuerpo. En esta teoría de la gestación, el aborto llega a ser indeseable, no porque representa una forma de homicidio o asesinato: finalmente, la persona social todavía no existe, ni el feto tiene una valoración humana e individual mientras no se haya bautizado. Más bien se teme el aborto porque podría soltar un pequeño ser pre-social en la forma de duende ancestral, que terminaría comiendo la sangre de las parturientas de la comunidad. ${ }^{116}$ Contra estos duendes anónimos existen medios de protec-

115 Para los aspectos adivinatorios de allqa, ver Cereceda: "A partir de los colores ...”; y para sus dimensiones cósmicas, ver Bouysse-Cassagne, Thérèse y Harris, Olivia: "Pacha: Sobre el pensamiento religioso aymara", en Albó (comp.): El Mundo Aymara ...

116 Cf. Morgan, Lynn M: "Imagining the Unborn in the Ecuadorean Andes". Feminist Studies 23, no 2, 1997. 
ción, y podemos — si queremos - relacionar su poder con los peligros de la hemorragia post-natal. Pero, en cuanto a la transferencia de las ideas culturales a los cuerpos de las parturientas, los duendes son actores en un más amplio drama social, cósmico y mitohistórico que, mediante el alineamiento ritual de correspondencias embutidas, se repite por cada parturienta en el proceso de dar a luz a un nuevo bebé. Su determinación de triunfar en su batalla con el feto agresivo se fortalece al saber que también otros están jugando un papel a su alrededor, ayudándola a traer a un nuevo cristiano solar del vientre del pasado lunar, que a la vez da poder a su propio vientre. En este sentido, el papel complementario del padre, de los especialistas chamánicos y de otros hombres que ofrecen su apoyo dentro de la comunidad, se considera muy valioso como un soporte fundamental para la mujer, justo como el soporte de las mujeres es necesario para los guerreros en las batallas sobre los linderos.

Los ritos post-natales de separación son necesarios para contrarrestar la sensación previa de la mujer de que su cuerpo estaba ocupado por un "diablito", cuyo avance hacia la vida cristiana podría costarle la suya. Los bebés se apartan del pecho, y su voracidad ancestral se reprime, antes de que se les permita tomar la nueva fuente cristiana de alimentación. La sangre roja interna se reemplaza por leche blanca, aunque el calostro puede ser considerado como "demasiado bueno" para el bebé. El problema de bonding no se presenta, porque la disciplina post-natal le predispone a tomar el pecho cuando finalmente se le ofrece. Una vez que se le da el pecho, sin embargo, se abandona la idea de disciplina, y el bebé puede alimentarse en cualquier momento y puede seguir mamando durante dos o tres años. ${ }^{117}$ Así, la socialización se construye al reemplazar la separación, la disciplina y una experiencia temprana de privación, con un retorno a la misma accesibilidad continua de la alimentación que el feto agresivo había disfrutado en el vientre, y que ahora se provee por los pechos de la madre.

A través de los ritos de separación, el infante andino aprende que solo puede sobrevivir en el mundo andino-cristiano controlando su hambre, y que a la privación de hoy seguirá la abundancia de mañana. La lección es psicológica, emocional y fisiológica, lo mismo que la interpretación y reacción materna frente a los estados cambiantes de su propio cuerpo durante el embarazo. Al mismo tiempo, la placenta, compañera del feto e intermediario uterino, tras mantenerse caliente durante algunos días, se elimina a

117 McKee, Lauris: "The Dieta: PostPartum Seclusion in the Andes of Ecuador", en Cohn, Anna, y Leach, Lucinda (comps.): Generations. Washington D.C., 1987. 
través del sacrificio, completando así la separación física de los dos polos allqa encarnados por la madre y su hijo. La construcción de la persona india andina surge, pues, de la conciliación entre la voracidad de los antepasados paganos y las disciplinas alimentarias de la sociedad andina-cristiana, alcanzada mediante la forma compleja de un psicodrama mito-histórico, que se estrena inconscientemente por la mujer y contribuye a formar parte del inconsciente del niño.

En su conjunto, y al nivel de un modelo general de la persona novocristiana del indio originario, tales procedimientos podrían relacionarse con los intentos de formar un tipo específico de personalidad, enraizada en la tierra y el subsuelo pagano, y capaz de resistir en este mundo la vida cristiana-solar de un "indio pobre y miserable". A la vez, retiene el acceso a recursos explosivos de energía y rebelión, que emergen exultantes de la persistente fuerza pagana en su interior, procedente a su vez de la piedrakamiri que infundía vida en el momento de su concepción. ${ }^{118}$ Además, la "conversión perenne" significa que el cristianismo no es una condición heredada por la sangre - como en algunas ideologías identitarias del Norte español cristiano-viejo-, sino que es un signo de socialización incipiente, que se recibe junto con el bautismo. Los cristianos nuevos, por definición, no pueden separarse enteramente de su propia esencia pagana. La sangre y la semilla proceden de los "diablos" subterráneos, y la vida del feto se origina entre las "almas" ancestrales (supay) de las minas. Aquí tenemos la base sustancial de la identificación política y jurídica del indio originario con la tierra.

Los datos etnográficos sobre el parto deben complementarse, entonces, con una externa "historia de los acontecimientos", si queremos comprender las implicancias de este paralelismo para la construcción de la persona india. La conversión amerindia en la América Hispánica debe considerarse en relación a la experiencia específica de la España de la Reconquista. El contraste conceptual entre sectores "puros" e "impuros" de la población hispánica se trasladó a América, donde corrió el riesgo de invertirse a la luz de la explotación colonial de los indios. Además, los españoles e hispanoamericanos con pretensiones de ser cristianos viejos (los únicos, teóricamente hablando, con derechos a trasladarse a América) solían trazar su ascendencia hasta una casa solar ancestral en un "lugar" particular de la Península. De ahí que los derechos hispánicos en América

118 La asociación entre piedras y formas concentradas de vitalidad se ha documentado en varias partes de los Andes. Ver Astvaldsson: "The Powers of Hard Rock"; y Las Voces de los Wak'a... 
fueron, inevitablemente, los de forasteros, ${ }^{119}$ que vivían en constante tensión con los "autóctonos" indios originarios. ${ }^{120}$

La idea de la autoctonía - aunque sea una ficción en términos biológicos - ha determinado la categoría social de los originarios hasta hoy, estableciéndose una contradicción ideológica entre la necesaria herencia de sustancia pagana y la eficacia de la conversión cristiana. Las aproximaciones indias al parto expresan, y en parte superan, esta contradicción. Al mismo tiempo, la oposición entre dos enfoques teóricos en el estudio de las sociedades indias andinas también se supera. Uno de estos enfoques enfatiza el mestizaje de facto, biológico y cultural, de todo habitante "indio", en cuanto producto histórico de olas sucesivas de conquista, cruces matrimoniales, colonialismo y transformación. Por el contrario, el otro enfoque enfatiza la persistencia indígena y su continuidad interna con sus predecesores precolombinos. Una posición busca desmitificar el indigenismo, tachándolo de "esencialista"; la otra defiende la "otredad" cultural y política de los indios andinos. Pero en Macha, ambas posiciones se combinan y se trascienden en una narrativa que subraya la repetida transformación, y reencarnación, de las almas paganas (supay) en bebés nuevo-cristianos. La sustancia "esencial" (alma) de los Chullpa ancestrales se transmite constantemente hacia la época cristiana, y con ella la coherencia de la categoría de originario, que remite a otras categorías de identidad, propiedad y posesión.

Y sin embargo, este psicodrama mitohistórico y fisiológico es también el resultado de una historia. Muchas de las prácticas descritas pueden encontrarse en España y en otras partes de Europa, y probablemente llegaron a los Andes en sucesivas oleadas de "modernización" global, desde el siglo XVI en adelante. ${ }^{121}$ Por otra parte, la idea de los antepasados como

119 Waman Puma traduce "forasteros" como mitimaes, palabra quechua que se refiere a los colonos andinos precolombinos que, trasladados a tierras lejanas, sea por sus familias, sea por los señores étnicos o por el Estado Inka, seguían manteniendo sus derechos a tierras familiares en sus lugares de origen.

120 Algunos "mestizos" (tomando esta palabra en su sentido social, no solamente biológico) pretendían gozar de ambas formas de legitimidad (p.ej. Garcilaso de la Vega, "El Inka"). Pero hasta ahora sabemos poco de las ideas y prácticas del parto en otros grupos marginados, tales como mulatos, zambos y otras "mezclas". La persistencia en las ciudades de algunos aspectos del panorama aquí descrito fue documentada por otros subproyectos dentro del proyecto global de Trinity College Dublin, financiado por la DG XII.

121 En 1541, por ejemplo, un médico mallorquín recomendó atar el cordón, después de cortarlo, a la pierna de la madre. Ver Carbón, Damián: Libro del arte de las comadres y del regimiento de las preñadas y paridas y de los niños. Mallorca 1541 [Biblioteca Nacional, Madrid, R100.135]. Las técnicas de extraer la placenta también recuerdan las empleadas en la España de mediados del siglo XVIII. Ver Ortiz, Teresa: "From hegemony to subordination: midwives in early modern Spain", en Marland, Hilary (comp.): The Art of Midwifery. Early Modern Midwives in Europe. Londres, 1993. Todavía no sabemos en qué medida tales prácticas también estaban presentes en las sociedades andinas pre-colombinas, o si reflejan, precisamente, oleadas previas de modernización europea. 
emanaciones líticas puede haberse vinculado con los orígenes de las almas fetales desde mucho antes de 1532, tanto en los Andes como en Europa. La relación colonial con el cristianismo misionero quizás haya acentuado los rasgos "diabólicos" del feto, agravando el maniqueismo psicológico y, como resultado, aumentando el dolor y la angustia experimentada por la madre. En los Andes, el énfasis sobre lo cristiano nuevo se marca por la experiencia específica de la Península, pero también reclama una continuidad de diferencia entre la civilización indígena precolombina y el "bárbaro" mundo colonial y republicano. Hoy, los indios comunitarios luchan por encontrar nuevas formas de adaptación a las últimas manifestaciones biomédicas de la "modernidad", que amenazan con eliminar una de las expresiones más íntimas de los derechos colectivos indígenas a la tierra.

La manera de construir la persona que aquí hemos analizado puede considerarse un caso de "esencialismo histórico", una idea que resulta perfectamente comprensible si reconocemos que la experiencia histórica necesariamente subyace en cualquier construcción de lo cotidiano. Al mismo tiempo, plantea preguntas importantes a los psicólogos y los psicoanalistas que se interesen en las experiencias fetales y del parto, en cuanto influencias que pueden contribuir fuertemente a los procesos formativos de la personalidad de los individuos. ${ }^{122}$ Las ideas y las prácticas andinas, con respecto a la separación y la reunificación de la madre y el bebé, obligan a realizar nuevos estudios clínicos y/o seguimientos de casos, para determinar en qué medida las teorías psicoanalíticas son limitadas a determinadas experiencias culturales e históricas, y si la experiencia andina — por ejemplo, de la privación temprana - se compensa con las sensaciones reconfortantes infundidas por otras prácticas, tales como los ritos de envoltura y la participación doméstica y familiar en el parto. Las actitudes hacia la comida y las reglas de etiqueta, que enfatizan la necesidad de compartirla equitativamente, junto con el valor positivo puesto sobre el "aguante" (muchuy) en diferentes contextos de la vida agropastoril altoandina (y que no puede atribuirse a ninguna "cultura de la pobreza", como sabemos por los estudios arqueológicos y etnohistóricos), son todos coherentes con los ritos de separación que hemos descrito. Por otra parte, es posible que la investigación futura muestre que estas "premisas básicas" del parto y de la formación de la persona son compensadas o modificadas durante el desarrollo de cada individuo, reduciendo el impacto de

122 Para una perspectiva clínica italiana sobre la influencia de la experiencia fetal en la psicología infantil, compárese Piontelli, Alessandra: From Foetus to Child: an observational and psychoanalytic study. Londres, 1993. 
algunos aspectos y acentuando otros, a tono con la veloz transformación producida en los últimos años en las sociedades campesinas y urbanas andinas.

Quedan por realizar nuevas investigaciones comparativas sobre las relaciones entre el "sostén psicológico" y la "función uterina", como recomienda Sheila Kitzinger, en otras sociedades sujetas a una religión ajena, que exige la conversión y el renacimiento espiritual. Debemos preguntarnos si también en ellas se fundan los derechos a la tierra en un concepto de autoctonía, que presupone la herencia de la "esencia" de los antepasados que vivían antes de la conversión religiosa. De esta manera, será posible plantear una teoría que tome en cuenta las diferencias en la formación de la persona en sociedades de diversas denominaciones cristianas en diferentes países, o en países que practican otras religiones que también han llegado mediante un proceso de conquista violenta. En el caso andino, es posible que las heridas infligidas hace muchos siglos no han terminado de tener sus efectos sobre la madre y los hijos, en la medida en que, hoy, éstos reproducen inconscientemente una experiencia traumática que sigue considerándose como fundadora de una determinada identidad social.

Pero la encarnación de esta transformación mito-histórica en los cuerpos de las mujeres parturientas también puede verse como un esfuerzo creativo, resultado de una intervención sostenida durante varios siglos, para consustanciar las identidades jurídicas con los procesos generativos de los individuos. Debemos preguntarnos si esta consustanciación puede eliminarse, sin poner en tela de juicio la persistencia de las propias comunidades indígenas que lo han puesto en práctica. El mismo concepto de "violencia" puede encontrarse sobre el tapete de discusión, en la medida en que las políticas biomédicas de salud reproductiva, como otros aspectos de la "modernidad", también presuponen la imposición forzada de nuevas prácticas. Estamos frente a un debate que tiene proyecciones importantes, a la hora de plantear la defensa de los derechos indígenas en las sociedades modernas, y al mismo tiempo lograr la reducción de la mortalidad materna de una manera que respete las ideas culturales y las prácticas etno-obstétricas que desean mantener las madres, no sólo en los Andes, sino también en muchas otras partes del mundo. ${ }^{123}$

123 Un proyecto de seguimiento, desarrollado a partir del Proyecto financiado por la DG XII, intentó averiguar en qué medida sería aceptable para las mujeres aymaras de La Paz esperar la salida de la placenta antes de cortar el cordón, en cuanto que esta práctica ofrece un sostén adicional al bebé después de nacer y ayuda a la placenta a separarse de la pared uterina. También cuenta con algún apoyo minoritario en algunas comunidades entrevistadas (cf. n 79). Ver Arnold, Denise Y., MurphyLawless, Jo, y otros: Prácticas apropiadas para mejorar las condiciones de atención postnatal de las mujeres bolivianas. Informe Final. Proyecto para la Embajada Real de los Países Bajos. La Paz, 1998. 